\title{
Metallophytes: the unique biological resource, its ecology and conservational status in Europe, central Africa and Latin America
}

\author{
ALAN J.M. BAKER, WILFRIED H. O. ERNST, \\ ANTONY VAN DER ENT, FRANÇOIS MALAISSE \\ AND ROSANNA GINOCCHIO
}

\section{Introduction}

Metalliferous soils provide very restrictive habitats for plants due to phytotoxicity, resulting in severe selection pressures. Species comprising heavy-metal plant communities are genetically altered ecotypes with specific tolerances to, e.g., cadmium, copper, lead, nickel, zinc and arsenic, adapted through microevolutionary processes. Evolution of metal tolerance takes place at each specific site (Ernst 2006). A high degree of metal tolerance depends on the bioavailable fraction of the metal(loids) in the soil and the type of mineralization. At extremely high soil metal concentrations, especially on polymetallic soils, even metal-tolerant genotypes are not able to evolve extreme tolerances to several heavy metals simultaneously. Adapted genotypes are the result of the Darwinian natural selection of metal-tolerant individuals selected from surrounding non-metalliferous populations (Antonovics et al. 1971; Baker 1987; Ernst 2006). Such selection can lead ultimately to speciation and the evolution of endemic taxa. Heavy-metal tolerance was first reported by Prat (1934) in Silene dioica and demonstrated experimentally in grasses by Bradshaw and co-workers in Agrostis spp. and by Wilkins in Festuca ovina in the late 1950s and 1960s (see Antonovics et al. 1971) and from the early 1950s onwards in the herb Silene vulgaris by Baumeister and co-workers (see Ernst 1974). Metal-tolerant plants avoid intoxication by an excess of heavy metals by means of special cellular mechanisms, as long as the soil metal levels do not exceed the levels of metal tolerance (Ernst 1974; Ernst et al. 2004). They can thus thrive on soils that are too toxic for non-adapted species and ecotypes. These unique plants with an ability to tolerate metal toxicities and survive and reproduce on metalliferous soils are called metallophytes. 


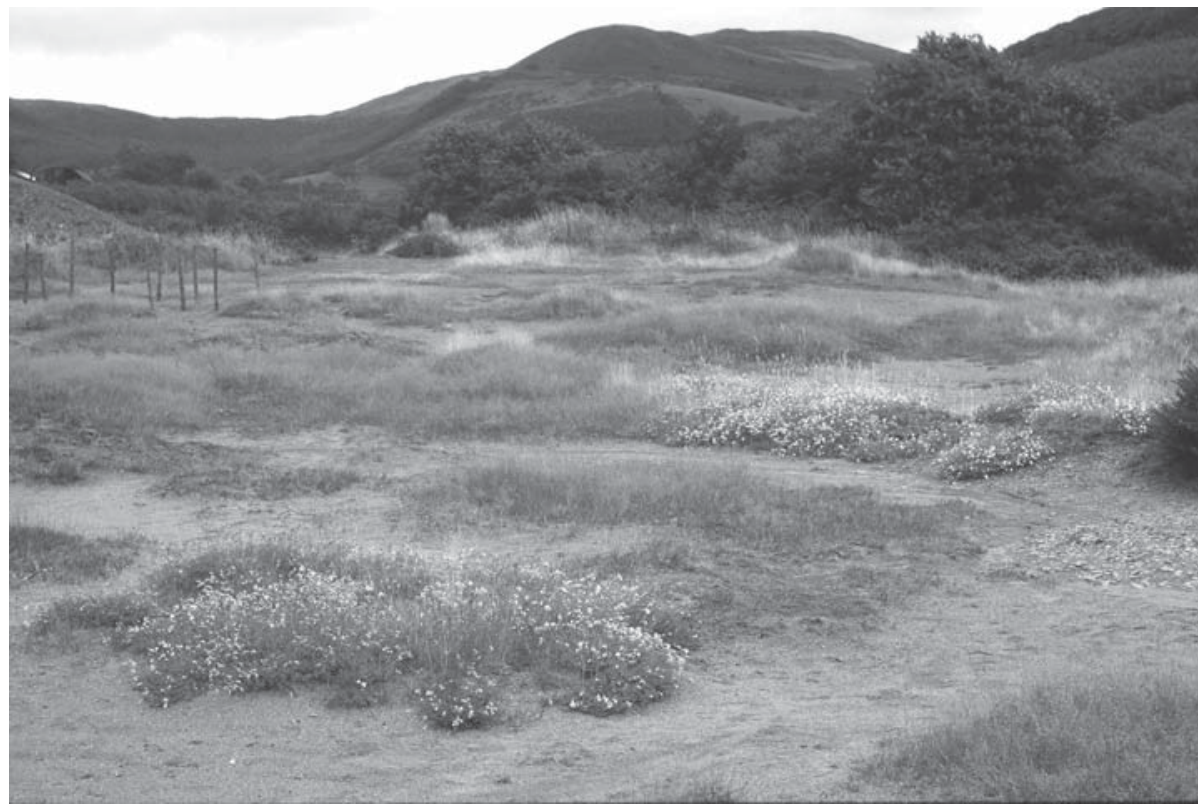

(a)

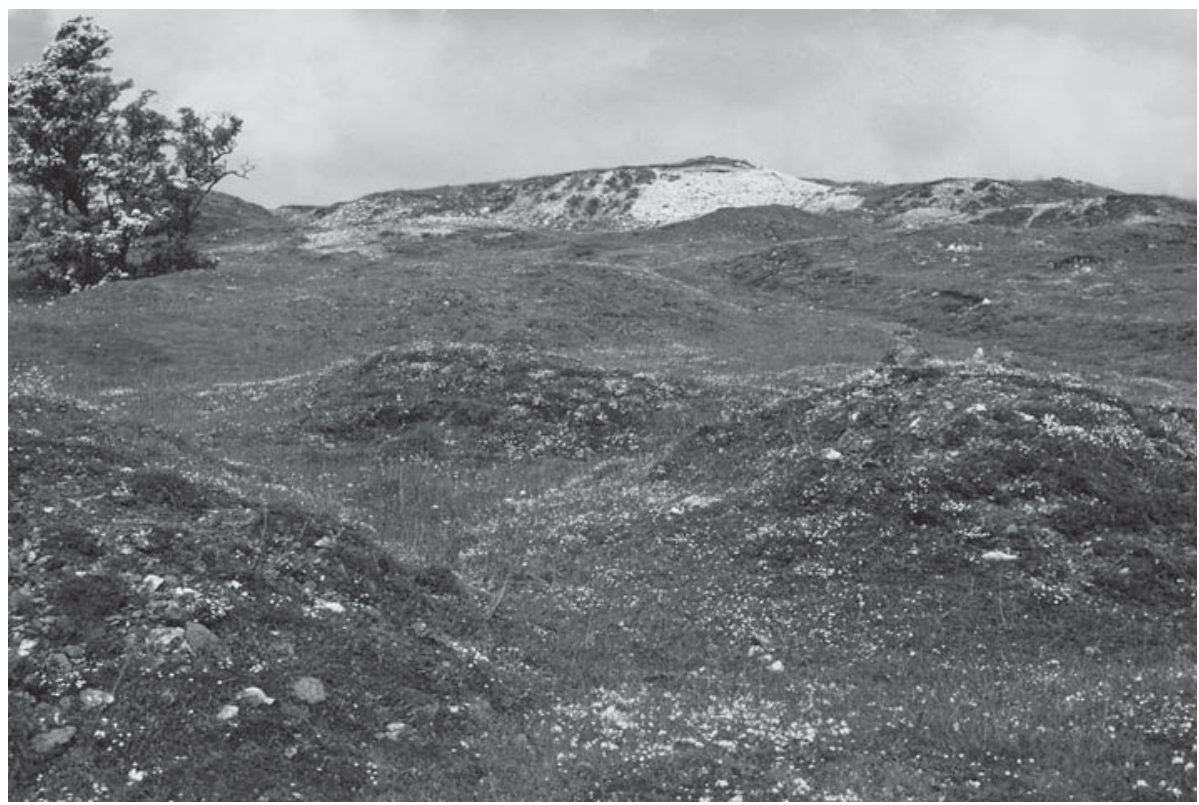

(b)

Figure 2.1. Metallophyte vegetation on ancient lead-mining sites in the UK. (a) Sparse cover of Agrostis capilliaris and Silene uniflora on acidic wastes at Goginan lead mine, central Wales; (b) Continuous metallophyte turf colonising superficial mine workings at Gang mines, near Matlock, Peak District. The calcareous substrate here and mosaic of metal contamination levels produce a rich assemblage of metallophytes including Minuartia verna in the most metal-contaminated areas. Photos: A. J. M. Baker. See colour plate section. 


\section{Heavy-metal sites and their vegetation in Europe Evolution and distribution of metallophytes}

After the last Quaternary Ice Age, forest developed on nearly all soils in Europe, except on those with extreme climatic or edaphic conditions. In the latter group are soils with elevated concentrations of heavy metals, too toxic for trees. In such situations, shadow-sensitive xerophytes were able to survive when they had the genetic advantages in metal tolerance (Ernst et al. 1992). Heavy-metal-tolerant vegetation was originally restricted to natural outcrops of metal ores, scattered as a relic of the Late Glacial epoch over Europe. Most of these habitats were destroyed or modified by mining activities from the Bronze Age onwards. However, metal mining has considerably enlarged the potential habitat range by creating further areas of metal-contaminated soils (Ernst 1990; Ernst et al. 2004). In Europe, sparsely distributed sites with metal-enriched soils form residual sanctuaries for metallophyte communities. Most sites are disconnected spatially and are of very limited extent. The UK has many sites in Wales (Davies \& Roberts 1978), the Peak District (Barnatt \& Penny 2004) and the North Pennines, and some isolated sites in Cornwall and in the Mendips (Ernst 1974; JNCC 2002). The central part of Germany is well-known for its heavy-metal vegetation (Schubert 1953, 1954; Ernst 1964, 1974; Becker et al. 2007). Alluvial heavy-metal vegetation occurs along the rivers Innerste and Oker in the Harz Mountains. In the Mansfeld area, several hundreds of large $\mathrm{Cu}-\mathrm{Pb}-\mathrm{Zn}$-mine spoil heaps are scattered with metallophyte communities (Schubert 1953; Ernst \& Nelissen 2000). In the European Alps in Austria, Slovenia and Italy, in the French Pyrenees, and several small sites are known in the Spanish Picos de Europa. The most studied and extensive communities are those of the three-border area of Belgium, the Netherlands and Germany, the Harz Mountains area and the Pennine orefield in the UK. Metallophyte vegetation makes up an important component of the biodiversity of Europe (Whiting et al. 2004).

Thalius (1588) was the first to recognise a relationship between the plant Minuartia verna and heavy-metal-enriched soils in the Harz Mountains, Germany. Subsequently, the association of the plant with lead-mine wastes in the Pennine orefield, UK, gave rise to its local name 'leadwort'. Schulz (1912) speculated that $M$. verna is in fact a glacial relict species surviving on heavy-metal soils as an isolated population; this was later confirmed by genetic analysis (Baumbach 2005). Libbert (1930) then defined the Armerietum halleri as a plant association specific to metalliferous soils, and the Violetum calaminariae was described from the Breiniger Berg near Aachen by Schwickerath in 1931. Plant associations specific to metal-enriched soils were thus recognised.

\section{Types of heavy-metal sites}

The history of metal sites determines the species composition of the vegetation. Three types of heavy-metal vegetation can be distinguished on syntaxonomy and on their occurrence: primary, secondary and tertiary. 
Primary sites

Primary sites are those with metallophytes where elevated concentrations of metals are due to natural mineralisation or ore outcropping, and not that which is anthropogenically influenced. Primary sites in Europe are therefore extremely rare today and mostly found as very patchy small sites in Central Europe, in the Pyrenees and in the Alps (Ernst 1974). Virgin sites like those in tropical woodlands and rainforests (Duvigneaud 1958; Brooks et al. 1985) are virtually non-existent, although many of the African sites are also threatened by mining activities (Leteinturier et al. 1999). Besides a high concentration of metals like zinc, lead, cadmium or copper in soil, heavy-metal vegetation types are characterised by a low nutrient availability. Hence, these plant communities are of very low productivity.

\section{Secondary sites}

Almost all primary metal-enriched sites in Europe have been anthropologically influenced by mining activities. These secondary sites result from mining activities, e.g., disturbed primary sites, spoil and slag heaps, ore processing and concentration (beneficiation) areas. The distinction between primary and secondary is often difficult to elaborate especially with ancient sites. Early mining has diminished most primary occurrences of metallophytes. From the Bronze Age to the late Middle Ages mining had a relatively low impact on the local environment. Metallophytes occurred locally on primary sites, and superficial mining created secondary habitats. Both habitat types were ecologically very similar. At that time mining was restricted to areas with metals outcropping. After the Middle Ages, much larger secondary habitats were created, often far away from areas with primary habitats, by deep underground mining or by metal refining on site. Exceptionally high concentrations of metals in soils at primary habitats result from weathering of natural mineralisation on well-developed soils. Modern secondary habitats, however, have a totally different substratum; mining has created soils with altered metal composition, depleted phosphorus and organic matter concentrations and low water retention capacity. Besides evolving metal tolerance, plants growing on these wastes were co-selected for tolerance to P-deficiency, resistance to drought and an ability to grow on loose substrates (Ernst 2000). This has affected the edaphic conditions and is a major cause of differences between primary and early secondary habitats.

\section{Tertiary sites}

Tertiary metal vegetation types can be subdivided into those communities whose genesis is a result of atmospheric deposition in the vicinity of metal smelters or alluvial deposition of metal-enriched substrates by sedimentation 
in river floodplains and on raised riverbanks. Tertiary atmospheric habitats originate by an input of a surplus of metals in a non-metal-enriched environment by industrial emissions (Baumbach et al. 2007) often far way from primary sites supporting metallophyte populations. They are often strongly influenced by acidification (by co-emission of sulphur oxides) whose effects are stronger than those of metals in soil. Species occurring at such sites have been selected from the local non-metal-enriched environment. These sites are frequently species-poor, e.g., monocultures of those grass species which have the ability to rapidly evolve metal tolerances such as: Agrostis stolonifera at the copper refinery at Prescot, England (Wu et al. 1975); A. capillaris at the Cd/Zn smelter at Budel, the Netherlands (Dueck et al. 1984); and Agropyron repens at the copper smelter at Legnica, Poland (Brej 1998). Sometimes metallophytes have arrived at smelter sites with the ores: an example is the moss Scopelophila cataractae in Wales and in the Netherlands (Corley \& Perry 1985; Sotiaux et al. 1987). An unintentional introduction of Armeria maritima subsp. halleri into the Littfeld area (Germany) may have been caused by mine workers when moving from the Harz area to new mining sites (Ernst 1974). Such 'transport endemism' (Antonovics et al. 1971) has probably been a major reason for the extended local distribution of metallophytes, such as Thlaspi caerulescens and Minuartia verna in the Pennine orefield, UK. Frequent visits by botanists may be the reason for the import of T. caerulescens to the Overpelt $\mathrm{Zn} / \mathrm{Cd}$ smelter site in Belgium and to its extended distribution in the Peak District, UK. Revegetation of tailings with poplar trees in the Auby smelter area in France was not successful; therefore, in the 1920s and in the 1950s Arabidopsis halleri and Armeria maritima subsp. halleri were introduced from Central European calaminarian grassland (Dahmani-Müller et al. 2000), and still show a good performance on the metalcontaminated soils around the Auby smelter (Bert et al. 2000).

Tertiary alluvial habitats are more of a natural kind and are generally species-rich, because they originate as a result of metal loadings to welldeveloped soils in riverine systems, often close to primary and early secondary sites (Van der Ent 2007). Downstream of mining activities, riverbanks have been flooded with metal-enriched materials and seeds of metallophytes since the Middle Ages in the Tyne valley, England (Macklin \& Smith 1990), in the Innerste and Oker valley in Germany (Libbert 1930; Ernst 1974; Ernst et al. 2004) and in the Geul valley in the Netherlands (Kurris \& Pagnier 1925). Due to leaching of heavy metals from the surface soils, the survival of this alluvial heavy-metal vegetation type depends on irregular metal replenishment by incidental riverbank flooding, such as in the Tyne valley in 1986 (Rodwell et al. 2007), and in the Innerste and Oker Valley in 1969 (Ernst 1974) and 2007 (Klein \& Niemann 2007). These heavy-metal-enriched sediments not only affect agricultural crops in other parts of the riverbank lands (Von Hodenberg \& Finck 1975), but also transfer propagules from 
metallophytes into the adjacent agricultural fields (Ernst 1974). In the Harz area, large dams have been constructed to avoid regular riverbank flooding to the detriment of maintaining the alluvial heavy-metal vegetation (Ernst et al. 2004). The alluvial tertiary sites of the Geul valley can be species-rich, but are extremely prone to eutrophication (Van der Ent 2007, 2008); here they originate from metal-ore dressing facilities.

\section{Classification of European metallophyte vegetation}

The heavy-metal content of soil is one of the most important edaphic factors determining vegetation composition. Heavy-metal toxicity of the soil, as well as low nutrient status, poorly developed soil structure and often water-restricted conditions maintain open vegetation, retarding succession. Many sites also harbour important populations of rare bryophytes, lichens and insects in addition to metallophytes. Being immobile, plants can survive only by adapting their physiological processes, and because metal tolerance is so specific, ecotypes of plants are restricted to individual sites, so-called 'local endemism'.

Heavy-metal plant communities of Europe are grouped within the vegetation order of Violetalia calaminariae. Ernst $(1974,1976)$ allocated alpine heavy-metal vegetation to the vegetation alliance Galio anisophylli-Minuartion vernae with Galium anisophyllum, Poa alpina, Euphrasia salisburgensis and Dianthus sylvestris and in the Italian and Austrian Alps the hyperaccumulator Thlaspi rotundifolium subsp. cepaeifolium and with the endemic Viola dubyana. In Western-central and Western Europe heavy-metal vegetation belongs to the alliance Thlaspion calaminariae with Arabidopsis (Cardaminopsis) halleri in addition to T. caerulescens (see also Brown 2001), and in Central Europe to the alliance Armerion halleri (see also Dierschke \& Becker 2008). The heavy-metal vegetation types in the Eastern Alps of Austria, Italy and Slovenia are included within the Thlaspion rotundifolii (Punz \& Mucina 1997), although in Slovenia T. rotundifolium is substituted by T. praecox (Vogel-Mikuš et al. 2007). In Scandinavia, Lychnis alpina is a marker species for metallophyte vegetation (Ernst 1974, 1990; Brooks \& Crooks 1979; Nordal et al. 1999). The Violetum calaminariae can be subdivided geographically in eastern and western areas with the blue flowering zinc violet (Viola guestphalica) in the Violetum calaminariae westfalicum at Blankenrode (Germany) its only site in the world, and the yellow flowering Viola lutea subsp. calaminaria in the Violetum calaminariae rhenanicum. In the British Isles, Rodwell et al. (2007) allocate the metallophyte vegetation as Festuca-Minuartia community to the calaminarian grassland of the Violetalia calaminariae.

\section{Classification of metallophytes}

The following classification of metallophytes is adapted from Lambinon and Auquier (1963): 


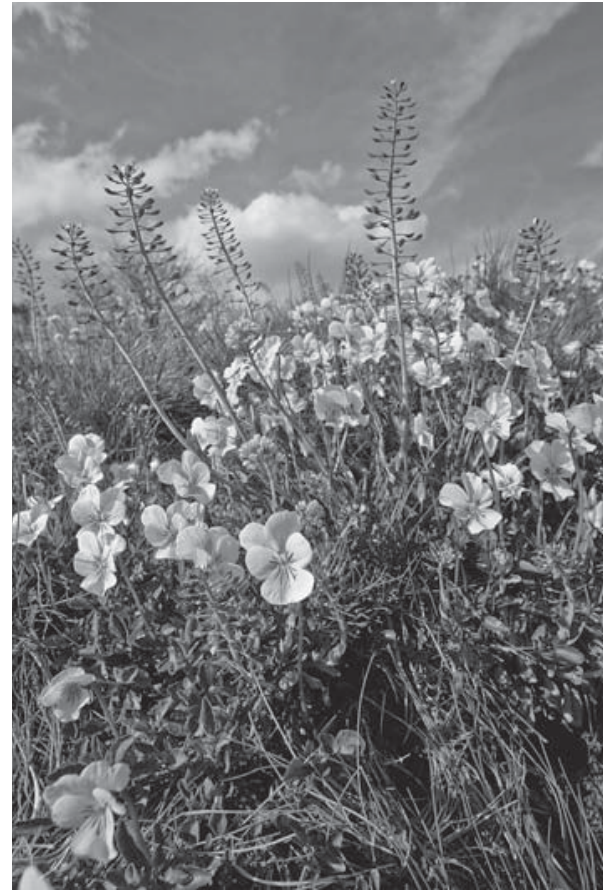

(a)

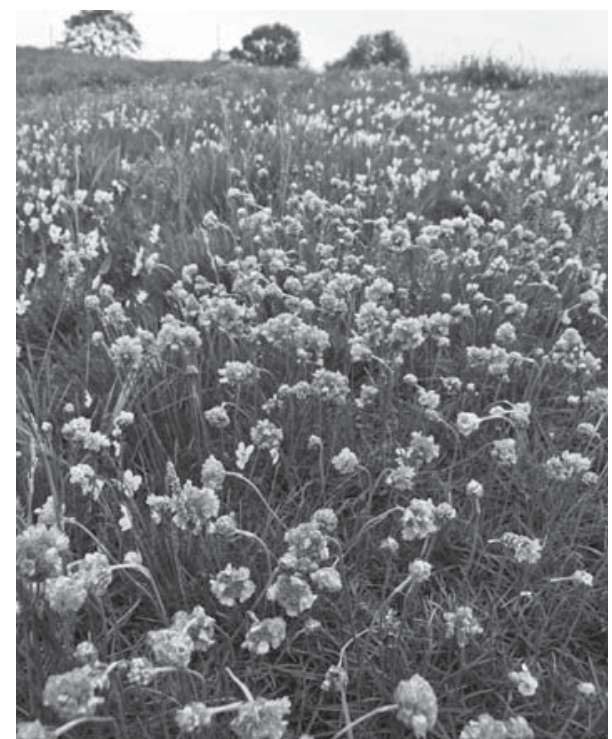

(b)

Figure 2.2. (a) Viola calaminaria, Festuca ovina subsp. guestphalica and Thlaspi caerulescens at the ancient mining site of Schmalgraf, Belgium. (b) Armeria maritima s.l., Viola calaminaria and Thlaspi caerulescens at what was one of the richest metallophyte habitats of northwestern Europe at Rabotrath, Belgium. Most of the metallophyte communities have disappeared in the last 4 years since the land was taken into agricultural production. Photos: A. Van der Ent. See colour plate section.

1. Metallophytes

a. Obligate metallophytes

b. Facultative metallophytes

2. Associate species

a. Metal-tolerant species

b. Non-metal-tolerant species

(1a) Obligate metallophytes: species with an exceptional tolerance to heavy metals in soils as well as a dependence upon the occurrence of these metals in soil. Some are also hyper-metal-accumulators ('hyperaccumulators'). They are not found outside this narrow ecologicalamplitude within the same phytogeographical area. These species are local endemics with sometimes a large geographical distribution. Examples are: Alyssum pintodasilvae (Dudley 1986), Viola guestphalica and V. lutea subsp. calaminaria (Hildebrandt et al. 2006; Bizoux \& Mahy 2007). 
(1b) Facultative metallophytes: genotypes or ecotypes/subspecies of common species with a specific tolerance to metals. They also occur in distinct nonmetal-enriched phytogeographical areas. The highly specialised ecotype, subspecies or genotype is dependent on the occurrence of specific metals in the soil. Examples are: Armeria maritima s.l. (Baumbach \& Hellwig 2007; Baumbach \& Schubert 2008), Minuartia verna s.l., Silene vulgaris (Ernst 1974) and Thlaspi caerulescens s.l. (Koch et al. 1998).

(2a) Associated metal-tolerant species: matrix species that are associated with the related plant association with a large ecological amplitude. They are either called 'pseudo-metallophytes' or 'accompanying species' of the true metallophyte vegetation. These species are moderately tolerant of heavy metals in soil, but not dependent on their presence. Examples of such species which are both common and have a wide geographic distribution are: Achillea millefolium, Campanula rotundifolia, Euphrasia spp., Plantago lanceolata, Polygala vulgaris, Ranunculus acris, Rumex acetosella, Thymus pulegioides, Agrostis capillaris, Holcus lanatus and Phragmites australis.

(2b) Associated non-metal-tolerant species from related associations, with little or no metal tolerance, the so-called 'indifferent' or 'accidental' species: these are usually weedy species, often annuals, showing neither vigour nor persistence on metalliferous soils.

Metallophytes can occur as a mosaic of patches in other vegetation classes: especially in nutrient-poor grasslands. The once very extensive alluvial tertiary metal vegetation in the Geul valley of the Netherlands and Belgium, for example, is a mixture with the association of Festucetum-Thymetum serpilli, characteristic for sandy soils, within the class Koelerio-Corynephoretea (Weeda et al. 2002), whereas the calaminarian grassland grows on clay soil on the riverbank (cf. Ernst 1978).

\section{Ecophysiology of metallophytes}

Up to now, no investigations have detected any specific metabolites in metaltolerant ecotypes. Metal tolerances are due to differential gene activities which are up- or down-regulating enzymes. In the case of metal uptake into the roots, there is a down-regulation of the high-affinity phosphate transporter in arsenic-tolerant plants (Macnair \& Cumbes 1987) or the elevated expression of Zn transporter genes (Assunção et al. 2001). Once the metal is in the cell, metaltolerant plants have modified the activity or the metal affinity of enzymes in such a way that a surplus of heavy-metal ions is rapidly removed from the plant cell metabolism to prevent physiological damage. These processes are metalspecific (Ernst et al. 1992, 2008; Clemens 2001). Examples are the over-expression of the metallothionein gene MT2b in Cu-tolerant ecotypes of Silene vulgaris and S. paradoxa (Van Hoof et al. 2001; Mengoni et al. 2003), cis-regulatory changes and triplication of the heavy-metal ATPase gene HMA4 in the Zn-hyperaccumulator 
Arabidopsis halleri (Hanikenne et al. 2008), the over-production of histidine in Ni-tolerant Alyssum spp. (Krämer et al. 1996) and the enhanced phytochelatin synthesis in As-tolerant Holcus lanatus (Bleeker et al. 2006). A high rate of $\mathrm{Cd}$ and $\mathrm{Zn}$ translocation from roots to shoots is essential for metal hyperaccumulation and differs between ecotypes of Thlaspi caerulescens (Xing et al. 2008). Within the leaves, metals have to be allocated to different cell types, showing a preference for epidermal cells (Chardonnens et al. 1999). Finally, there is a restricted metal transport into the seeds (Ernst 1974), so that the young seedling is not already loaded with metals. All these different aspects of metal metabolism can explain that an exposure of metal-tolerant plants to metals results in the modification of hundreds of enzymes, as evidenced by transcriptomes and proteomes (Tuomainen et al. 2006; Weber et al. 2006; Hammond et al. 2006). These multiple reaction patterns indicate that there is still a long way ahead for understanding all aspects of metal tolerance mechanisms (Clemens et al. 2002).

As established by Mendelian genetics, the number of genes necessary for tolerance to cadmium, copper and zinc per se are two for each element, with many modifiers determining the degree of metal tolerance (Bröker 1963; Macnair et al. 1993; Schat et al. 1996; Bert et al. 2003). In addition to any prevailing metal toxicities, metallophytes have also to adapt to other extreme chemical and physical soil factors (Baker 1987), such as dry soils, by structurally enhanced proline levels (Schat et al. 1997), differences in calcium status (Zhao et al. 2002), iron availability (Lombi et al. 2002) and sulphur supply (needed to synthesise adequate amounts of metal-binding compounds) (Ernst et al. 2008). The low availability of the major nutrients nitrogen and phosphorus (Ernst 1974), characteristic of open oligotrophic environments, requires metal-tolerant plants to evolve a high degree of major nutrient efficiency, especially on secondary and most tertiary metal-enriched sites. Heavy-metal-resistant ecotypes do not occur on non-polluted soils. As most species in ecosystems with moderately vegetated soils, metallophytes are sensitive to shade (Schubert 1953; Kakes 1980). The most shade-sensitive species is Minuartia verna, already disappearing during vegetation succession on metalliferous soils (Ernst 1964, 1974, 1976). Examples of populations of Thlaspi caerulescens which have managed to maintain stable populations on small metal-enriched, shadowed patches in woodlands are at Aberllyn zinc mine (N. Wales) and at the Silberberg near Osnabrück (Germany). Mechanisms of adaptation are energy-expensive, and plants that can tolerate high concentrations of heavy metals are thus weak competitors (Wilson 1988; Ernst et al. 1992).

Most species of heavy-metal plant communities have a symbiosis with arbuscular mycorrhizal (AM) fungi, which by binding metals in the fungal cells prevents the host from damage (Griffioen et al. 1994; Pawlowska et al. 1996; Hildebrandt et al. 1999; Tonin et al. 2001; Turnau \& Mesjasz-Przybylowicz 2003; Whitfield et al. 2004). Colonisation by AM fungi is almost absent in M. verna, 
Silene paradoxa, S. vulgaris (Caryophyllaceae), Alyssum spp., Arabidopsis halleri, Biscutella laevigata, Cochlearia pyrenaica and all Thlaspi spp. (Brassicaceae) on heavy-metal-enriched soils (Regvar et al. 2003). Metalliferous soils are extremely restricted habitats, posing a strong Darwinian challenge to candidates for survival. This combination of intense selection with restricted location promotes microevolution and speciation processes on sites (Antonovics et al. 1971). Metallophytes are typically endemic to their native metalliferous sites and, as a result, have a very restricted geographical distribution (Baker \& Brooks 1989).

\section{Conservation and management of metallophyte communities in Europe \\ Threats}

A species can be considered rare when it meets one or more of the following three criteria: restricted geographical distribution; a habitat with restricted ecological conditions; or small population size (Olivieri \& Vitalis 2001), though rarity in itself does not constitute a threat of extinction. Soils with elevated metal concentrations, however, are extremely fragmented and dispersed habitats in Europe, often forming small geographically isolated 'islands' in areas of background vegetation with non-elevated metal concentrations (Baker \& Proctor 1990). Because of their restricted geographical distribution and very limited ecological amplitude, metallophytes are prone to extinction due to habitat destruction. This results in genetic drift, demographic stochasticity and inbreeding (Bizoux et al. 2004). Rare endemic metallophyte species or ecotypes are, therefore, priority targets in biodiversity conservation programmes.

Heavy-metal vegetation is a fragile community type and frequently faces a severe threat of extinction leading to absolute rather than local extinction of metallophytes. The main threats to metallophyte vegetation include: (1) agricultural reclamation, application of herbicides, and application of fertilisers and lime, causing eutrophication in the nutrient-poor metallophyte communities; (2) vegetation succession due to lack of active ecological management; (3) soil remediation enforced by regulatory agencies and (4) site destruction due to mining, gravel extraction, landscape development or tree-planting.

\section{Decline}

The designation of metallophyte habitats as 'wastelands' or 'derelict land' in need of rehabilitation has been largely responsible for the disappearance of most metallophyte communities in the last decades. Metallophyte habitats are variously regarded as ecologically degraded sites, derelict brownfields, environmental problems, wastelands and pollution threats. This has resulted in an unambiguous European-wide effort for site rehabilitation and remediation. Sites were either made suitable for agriculture, levelled, used as waste dumps or for gravel and aggregate production, or built upon with industrial developments. 
Remediation and land reclamation of metalliferous mining sites is often in direct conflict with conservation efforts (Johnson 1978). In Natura 2000, calaminarian grasslands are considered as Special Areas of Conservation under the Code 6130.

Regulatory drivers seem strongly biased to classify sites as either 'clean' or 'polluted'. Instead of considering metallophyte habitats 'polluted', which implies negative value and determines ontological consequences (namely rehabilitation to clean background conditions), sites could be considered as 'metal-enriched'. Metallophyte habitats present metal-enriched islands in a sea of background concentrations of metals. Landscape heterogeneity with environmental gradients, even in what is considered a pollution scenario, drives biological diversity. The intrinsic quality of metal-enriched sites enables the development of endemic metallophyte communities. Many sites have been destroyed on the assumption that chemically and physically hostile environments are biologically insignificant (Johnson 1978).

Habitats of metallophytes are in conflict with common existing perceptions of naturalness. The influence of humans in pristine undisturbed habitats is generally considered negative in ecocentric nature visions (Keulartz 2005). Restoration ecology is tailored to deal with these alterations (i.e., mining demands) of the environment to the original natural situation. Anthropocentric nature visions, on the other hand, consider metallophyte habitats as industrial wasteland. Metaphors like 'ecosystem health' subscribe rehabilitation to chemically, physically and ecologically degraded systems. It is generally anticipated in nature policy that strongly modified environments do not possess significant natural and biodiversity values (Lenders et al. 1997).

In former decades and centuries metallophyte habitats are considered at best valueless (and ignored), causing environmental problems and were seen as an industrial blemish on the landscape. Many sites have been efficiently eliminated from the landscape in the last decades (Smith 1979). Due to changed awareness, they are currently protected in Europe by the Habitat Directive. Most mined areas have a long history of mining and the evidence is the remains of the former mining industry that shaped the landscape. These relicts (including metallophyte communities) are part of the heritage value of a specific area. Eliminating these elements from the landscape, even if they are considered scars, cleans a landscape of its past. Today most landscapes are now heavily human influenced, and the discrepancy in policy between natural and anthropogenic genesis of a site is virtually non-existent in the ecology of metallophyte communities. Moreover, history can add to natural values. Besides land reclamation and remediation, metallophyte communities face the same fate as most other nutrient-poor communities such as chalk grasslands in the last century which depended on extensive traditional agriculture. European metallophyte communities have experienced a large-scale decline 
due to modern intensive agriculture and its application of fertilisers and lime. Some specific examples can be cited.

Currently, the large landscape characteristic spoils heaps of the Mansfeld area in Germany face complete destruction of the metallophyte habitat. Tailings continue to be removed for use as road construction materials. With the increasing prices for copper, these historic spoil heaps are scheduled for reworking. At other sites, spoil heaps dating back to the Middle Ages and today lying amidst agricultural fields (Schubert 1953; Ernst 1974) have been removed, but the soil underneath the spoil heaps, often related to copper shales, is still so highly metal-enriched that the agricultural crops (wheat, sugar beet) are very chlorotic and yield poorly. In the Harz Mountains, the materials from many tailings areas were used for highway construction, still visible by the metallophytes on the verges of the Göttingen-Kassel highway (Germany). Secondary sites in the Stolberg and Eschweiler area in Germany were used as landfills for waste, and have subsequently disappeared. Another tailings site was revegetated, but unfortunately used as a children's playground, resulting in symptoms of $\mathrm{Cd}$ and $\mathrm{Pb}$ toxicity in those children consuming leaves of Rumex acetosa, a plant species with a high accumulation capacity (MAGS 1975). The locus classicus for the Violetum calaminariae, the Breiniger Berg near Aachen is now partly overgrown by Pinus sylvestris trees.

In the UK Peak District, over 75\% of all remnants of the lead mining industry (especially rakes and surface works with metallophyte communities) have disappeared, mainly due to agricultural improvement of pasture in the last two centuries (Barnatt \& Penny 2004).

Plombières in Belgium was a 30 ha ancient secondary site well-known for its assemblage of rare species (Simon 1978). Only 5 ha remain today after a largescale remediation project involving surface capping with 'clean' soil in 1996. Casino Weiher Halde at Kelmis, also in Belgium, is the site of the former Altenberg mine, worked since Roman times. The site has largely disappeared due to the building of shopping premises. After construction of houses on the site in 2007, the last remaining part is now designated as a nature reserve. Based upon a 1962 mapping and a site visit in 2006, it is estimated that of the former 5 ha heavy-metal vegetation, only c. 1 ha remains, a loss of around $80 \%$ (Ernst unpublished data).

The once extensive tertiary alluvial metallophyte vegetation along the Geul River of the Netherlands and Belgium covering over $18 \mathrm{~km}$ on both sides of the border have nearly completely disappeared due to intensive agriculture. Over 99\% has disappeared since 1925 and only 0.5 ha now remains (Van de Riet et al. 2005). The best-developed site was destroyed by the construction of a trailer park in the late 1970s. At nearby Rabotrath well-developed tertiary metallophyte vegetation could be found up until 2005, when these meadows were also put under agricultural practice, and have since diminished substantially. 


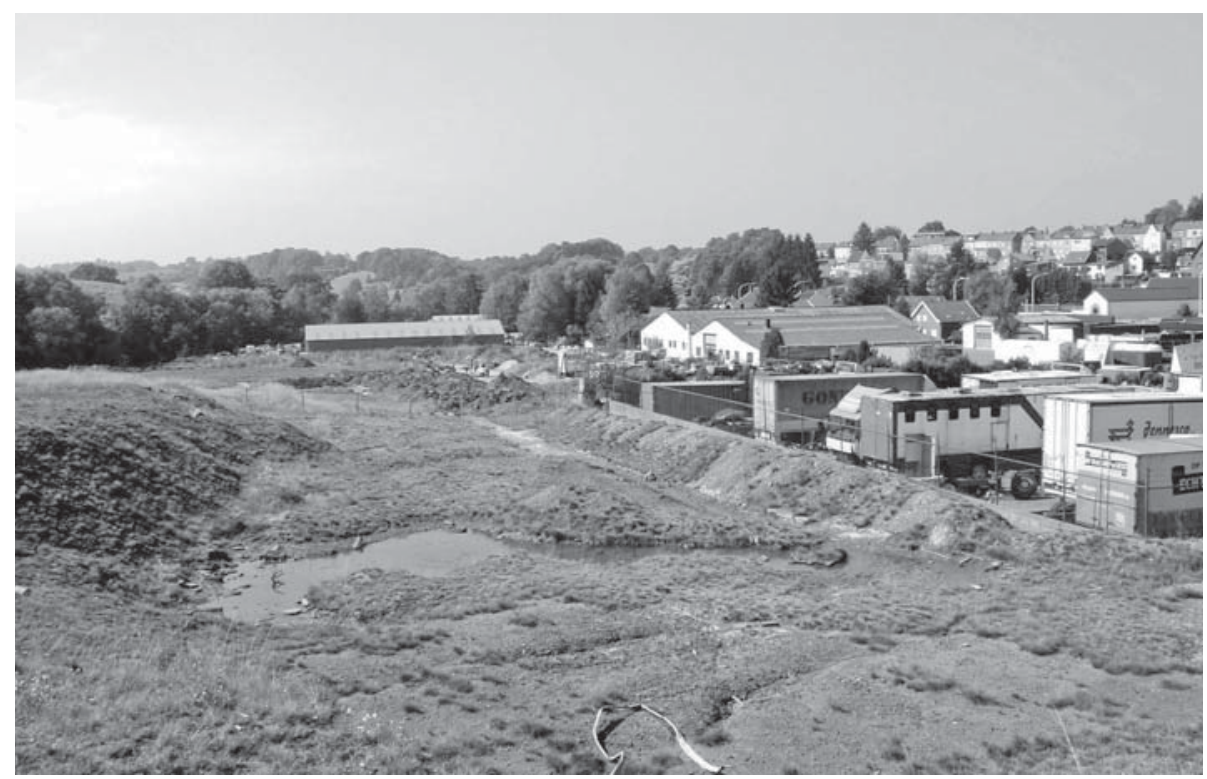

(a)

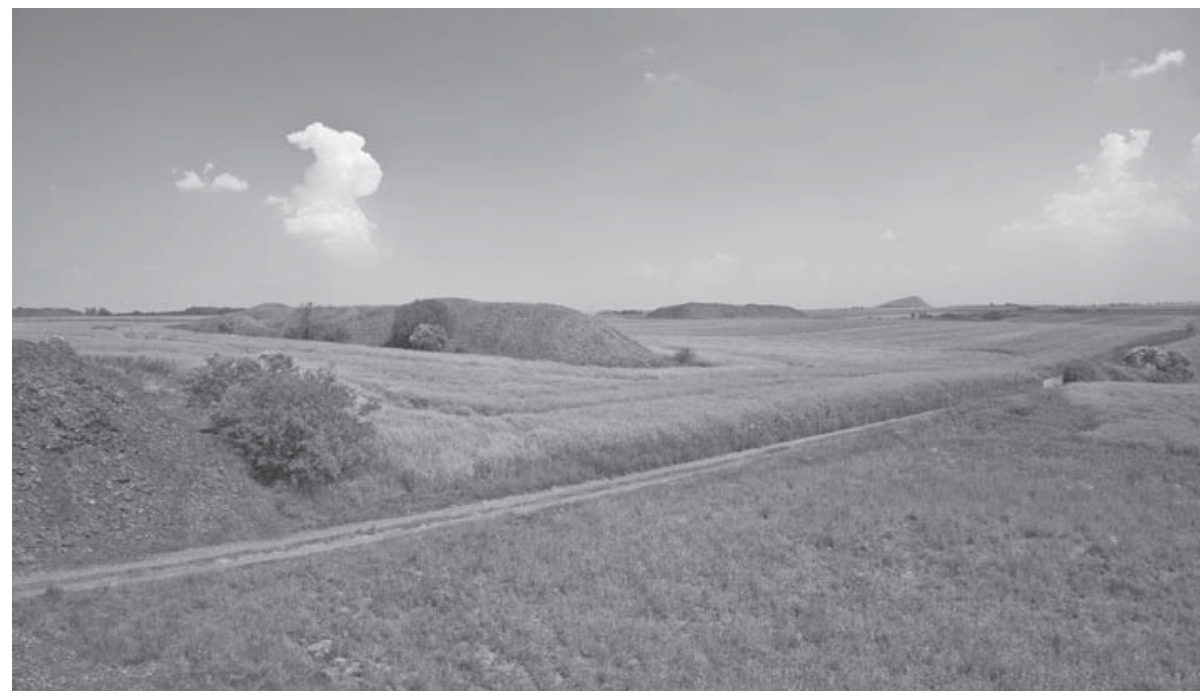

(b)

Figure 2.3. (a) Casino Weiher Halde, Kelmis, Belgium. At this site, the former Altenberg mine which operated from Roman times until its closure in 1882. Despite legal protection, the site is now dominated by shopping lots and industrial premises. On the small fragment that remains, Silene vulgaris, Minuartia verna subsp. hercynica, Festuca ovina subsp. guestphalica, Viola calaminaria, Armeria maritima s.l. and Thlaspi caerulescens occur abundantly. (b) Spoil heaps east of Hettstedt, Germany, from the mining period 1780-1815 now set in an agricultural landscape bear only a sparse vegetation cover mostly of highly specialised ecotypes of Silene vulgaris. In the background, the conical tailings tip is from the twentieth century; there is only a cover of ruderal vegetation at its base due to the hostile edaphic conditions. Photos: A. Van der Ent. 
In Belgium, the total coverage of the association Violetum calaminariae encompasses only 38 ha, almost exclusively of the secondary type (Graitson et al. 2003). The quality of the majority of these sites has deteriorated in the last decades due to lack of management (Van der Ent 2007). Succession has resulted in many sites being overgrown by shrubs and trees. The impact of fertilizers and atmospheric deposition of nitrogen on nutrient-poor grasslands has accelerated this process.

Immediate action in pragmatic site management is imperative to protect remaining metallophyte vegetation in Europe; this must be given priority in nature conservation. It is clearly possible to regenerate secondary and tertiary sites as Raskin (2003) and Van der Ent (2008) have shown. Urgent action towards protecting metallophytes is also necessary because of the ever-increasing threat of extinction and the rapid decline in the number of sites. Today almost nothing is left of the former distribution compared to 50 years ago.

\section{Site management}

Depending on metal concentrations in the soil, metallophytes can thrive on primary sites for thousands of years, on secondary sites for perhaps hundreds of years, and on tertiary sites for less after the cessation of mining activities. Metallophytes on secondary and tertiary sites are relics of local historic land use and dependent upon site dynamics. To sustain the metallophyte communities, ecological management is necessary. Without management, these plant communities face extinction due to vegetation succession and substrate attenuation.

Most sites are small-scale, but are habitats for highly endangered plants and can therefore be classified as especially valuable for nature conservation (Pardey 2002). Conservation management of metallophytes is strongly linked to maintaining sites with high metal concentrations in the soil. To conserve and develop secondary sites, disturbance and mixing of topsoil/subsoil is necessary to sustain concentrations of metals high enough to hinder the succession of grasses and herbs. Because metallophytes are generally of very low productivity and, hence, uncompetitive, eutrophication remains a serious threat. Site management includes mowing and removal of hay, and/or removal of the top layer of soil to reduce nutrient loadings (especially $\mathrm{P}$ ) in the system and retard vegetation succession.

\section{Environmental legal protection within Europe}

In contrast to former times, metallophytes are protected by legislation Europewide. This protection strengthens conservation and can contribute to the restoration of metallophyte vegetation. Under the EU Habitats Directive Annex I (Fauna-Flora-Habitat), heavy-metal vegetation is coded as 'Calaminarian grasslands of the order Violetalia calaminariae' under Code 6130. This also 
includes assemblages of metal-tolerant lower plants on mine waste, even if higher plants are absent. EUNIS Habitat Classification coded 'Heavy-metal grassland' E1.B2a, and Natura 2000 coded as 34.221 with 92/43/CEE I nonpriority protection. EUNIS, the European Environment Agency Biodiversity Database, lists per country the Netherlands 1, Belgium 6, Germany 35, Italy 3, France 3, Spain 1 and the UK 23 sites, with 'calaminarian grasslands of the order Violetalia calaminariae’ under Code 6130.

In Germany, five Federal States designate legally protected biotopes under $\S 30$ of the Federal Nature Conservation Act. In the State of Nordrhein Westfalen (NRW), which hosts important metallophytes sites, calaminarian grasslands are protected as a 'Protected Area' following $\$ 30$ Bundesnaturschutzgesetz and as $\$ 62$ Landschaftsgesetz NRW, Nature Reserve (NSG) and/or Protected Landscape Elements (LB). There is also the 'Naturschutz-Rahmenkonzeption Galmeifluren NRW' (Pardey et al. 1999) ('Concept for conservation of heavy-metal vegetation'), which is an important instrument for efforts to conserve metalliferous vegetation types. In the Netherlands, the remaining tertiary metal vegetation was protected as a nature reserve in 1954, the first site in the world where an industrially contaminated site was protected by law. In Belgium, with its extensive metallophyte sites in the Walloon region, most are cited in CORINE (Inventaire des sites d'importance majeure pour la conservation de la nature dans la Communauté européenne), in ISIWAL (Inventaire des Sites Wallons d'un très grand intérêt biologique) and in SGIB (Sites de Grand Intérêt Biologique). Most species of heavy-metal vegetation in Germany, the Netherlands and Belgium are listed on the National Red Lists and are protected by the National Species Protection Acts. In all three countries, many sites are also being included in the Natura 2000-network, and additionally in the Netherlands a 5-year national research programme and restoration plan is currently being implemented for the conservation of metallophyte vegetation (Van de Riet et al. 2005).

Often conflicting with the legal protection of metallophyte species are National Soil Protection Acts and Environmental Hygiene Acts, which require 'remediation measures' for heavily contaminated soils, and thus their habitat destruction. Further, NGOs have for decades been demanding that the pollution of the environment be reduced, similarly supporting metallophyte habitat destruction.

Metallophyte communities are not only ecological interesting entities, they also amount to a cultural-historical account, an archaeological record. The restoration and conservation of historic metal-mining sites can be seen as a practical measure within the spirit of the European Conference on the Conservation of Archaeological Heritage (European Convention on the Protection of the Archaeological Heritage; Valleta, 16I 1992). Most governmental bodies distinguish between 'natural' occurrences (primary sites) and man-made (secondary) sites, like mining spoil heaps; the more natural are given priority. Because of their rarity and ecological status, primary sites are important 
but historical interest can add value to anthropogenic sites. Discussion as to whether sites are natural or anthropogenic has centred less on ecology than on the demands of legislation, which designate heritage status based upon industrial archaeological values.

\section{Heavy-metal vegetation in Central Africa}

In Central Africa, there are a lot of sites enriched with cobalt (Duvigneaud 1959), copper (Duvigneaud \& Denaeyer-De Smet 1963; Wild 1968; Brooks et al. 1992a) and nickel (Wild 1970) and only a few soils have high levels of lead and zinc (Ernst 1972). The greatest interest has concentrated on the flora on the cobalt and copper outcrops in Katanga (Brooks et al. 1985).

\section{The copper-cobalt metallophytes of Katanga}

The copper-cobalt flora of Katanga (Democratic Republic of Congo) is without doubt the richest described to date globally in terms of numbers of endemic metallophytes. Our knowledge of this flora has emerged from alternating periods of active exploration with periods of total inactivity. This progression has been, and still is, linked to efforts on several fronts but primarily from a knowledge of the existence of Cu-Co outcrops and site accessibility. Subsequent collection of plant materials (and later also soils), taxonomic works, a few systematic studies and biogeochemical investigations have followed.

\section{Historical perspective}

Five broad periods of progress may be recognised (Leteinturier 2002; Leteinturier \& Malaisse 2002). Although local mining activities in Katanga commenced as early as the fourteenth century (De Plaen et al. 1982), the first plant collections from Cu-Co sites were made by Rogers probably around 1910, and certainly in 1914 at the Étoile du Congo mine. Other collections in this first period were made by Burt-Davy (1919), Rogers (1920), Robert (1921), Robyns (1926), Quarré (1937, 1939) and by priests from Saint François-de-Sales (1939). Only one paper (Robyns 1932) was published in this period; it provides a list of the first 45 Katangan copper metallophytes recorded. From 1940 to 1953 further collections were few and erratic, and included those by Hoffman (1946) and Duvigneaud (1948). A second period extended from 1954 to 1963 with independent plant collections from the Cu-Co outcrops by Duvigneaud and his collaborators and by Schmitz. Duvigneaud collected at least 3704 voucher specimens, and the number of Cu-Co metallophytes was raised from 72 (Duvigneaud 1958) to 218 (Duvigneaud \& Denaeyer-De Smet 1963). Other collections during this period are rare, but include those of Symoens (1956-1963), Plancke (1958), Bamps (1960) and Ledocte (1960). From 1963 until 1978, few occasional collections were made (Evrard \& Léonard in 1968, Lisowski 1968-1971, Bercovitz 1971, Breyne 1977 and Pauwels 1978). A third period of botanical exploration started 
in 1978 with great attention devoted to Cu-Co sites by Malaisse and Brooks. This period extended until 1986. Nearly 2000 voucher specimens were collected, resulting in 17 publications (see, e.g., Malaisse et al. 1983). Other investigations were made by Shewry et al. (1979), Wechuyzen, and a diverse group of botanists from the Belgian National Botanic Gardens. The fourth period stretched from 1987 to 2002; sporadic collections of plants were made and 14 publications appeared. Two surveys are to be highlighted: one in the Tenke-Fungurume area by Malaisse, Dikumbwa, Kisimba and Muzinga, and the other on copper sites in southcentral Africa, including Katanga by Leteinturier, whose $\mathrm{PhD}$ thesis (Leteinturier 2002) greatly advanced our knowledge of the Cu-Co metallophytes, listing 548 taxa.

Since August 2003, the fifth period, a new Congolese policy was implemented permitting 1644 mining titles in Katanga for Cu-Co sites to about 200 different mining societies. Their activities have to comply with the requirements of the applicable laws of the Democratic Republic of the Congo (DRC), notably Mining Law 007/2002 and Decree 037/2003. Mining companies are required to carry out an Environmental and Social Impact Assessment (ESIA), which in turn results in a Biological Diversity Action Plan (BDAP). Botanical surveys are part of the BDAP but are very rarely undertaken $(<5 \%$ of the mining titles), and very fanciful BDAPs have been submitted and accepted by the Department of Environment of the Ministry of Mines. Examples consist of surveys giving only poor comments on woodlands but nothing regarding mineralised areas that were never visited. Moreover Latin names of plants are inaccurate and frequently misspelt. Such a situation results in complete destruction of $\mathrm{Cu}-\mathrm{Co}$ flora and vegetation from mining activities conducted by most of the so-called 'mining societies'. Moreover, some sites delivered for mining have not commenced any operational activities. This has provided a unique opportunity for more than 50000 (maybe even 100000) men and boys (aged 6 years and above) to be involved in illegal mining. These 'miners' collect heterogenite, a cobalt oxide $[\mathrm{CoO}(\mathrm{OH})]$, which is sent to South Africa without any importation tax at the border, made possible through a CongoleseLibanese network. About 30 trucks each with 300 sacks of heterogenite move daily to the south. In some places, small villages of 300 people involved in illegal mining have been established. This artisanal activity is of great importance for the survival of these small communities, but surface injury to the steppe-savanna vegetation may reach near total destruction. Heaps of sterile rocks and shallow pits produce a lunar desert landscape devoid of all plant cover.

\section{The current state of knowledge}

The actual number of Cu-Co ore bodies in Katanga is far above that documented in 1960. If 150 sites have received some botanical investigation (from 
one to more than a thousand vouchers collected), at least some 150 others have never been explored; some of these sites may have already been totally destroyed. Since 2005, an important plant collecting initiative has taken place. Some 5000 voucher specimens have been collected in less than 4 years, about $39 \%$ of the total collected since 1914 . However, these collections presently need to be carefully checked for naming and classified regarding Cu-Co metallophyte biodiversity. At least $15 \%$ of previous collections are in the same situation, awaiting assignment of correct scientific names. It has been estimated that more than 700 higher plant species exist on the Katangan Cu-Co outcrops, but the real figure could in fact be much higher. How many species new to science are in these collections? To what extent are they copper-cobalt endemics? Leteinturier (2002) already highlighted the time extending between a collection and the description of a new taxon, a few years even up to 50 . Several families and genera of the flora of southcentral Africa (Flore d'Afrique centrale, Flora Zambesiaca, Flora of Tropical East Africa) are in need of revision, and this adds a further complication. A good example is given by the genus Basananthe Peyr. (Passifloraceae). Revision of the material hosted in the National Botanic Garden of Belgium (BR) has allowed the description of six new species, all from Katanga, including two species restricted to Cu-Co sites (Robyns 1995; Malaisse \& Bamps 2005). On the other hand, a re-evaluation of the copper indicator Haumaniastrum katangense (Lamiaceae) comes to the conclusion that this species is more widespread on soils with low $\mathrm{Cu}$ levels than on those with high ones (Choo et al. 1996). The Zambian copper flower Becium homblei (Lamiaceae) has lost specific rank; it is now considered nothing more than a Cu-tolerant ecotype of Becium centrali-africanum (Sebald 1988), the species mostly occurring on low-Cu soils.

Data concerning heavy-metal tolerance and accumulation in the Cu-Co flora have also to be reviewed thoroughly. Very few experimental studies under controlled conditions have been performed to date (see, e.g., Baker et al. 1983), and there is an urgent need to confirm the putative status of the $35 \mathrm{Cu}-$, and 36 Co-hyperaccumulators listed by Reeves and Baker (2000). Fine superficial dusts tightly adhering to dried herbarium specimens may account for the variable and possibly spurious apparent hyperaccumulation values published in early biogeochemical studies (Brooks et al. 1987). Several experimental studies on metal uptake and localization in the metallophytes of Katanga are currently under way.

\section{Conservation and management of the Cu-Co metallophyte flora}

Conservation of the $\mathrm{Co}-\mathrm{Cu}$ metallophyte diversity in relation to current and future mining activities is a major challenge. A few mining groups have, however, recognised the issues and developed excellent scientifically based conservation strategies. The operations at Luiswishi and Tilwezembe mines are good examples (Fig. 2.4). 


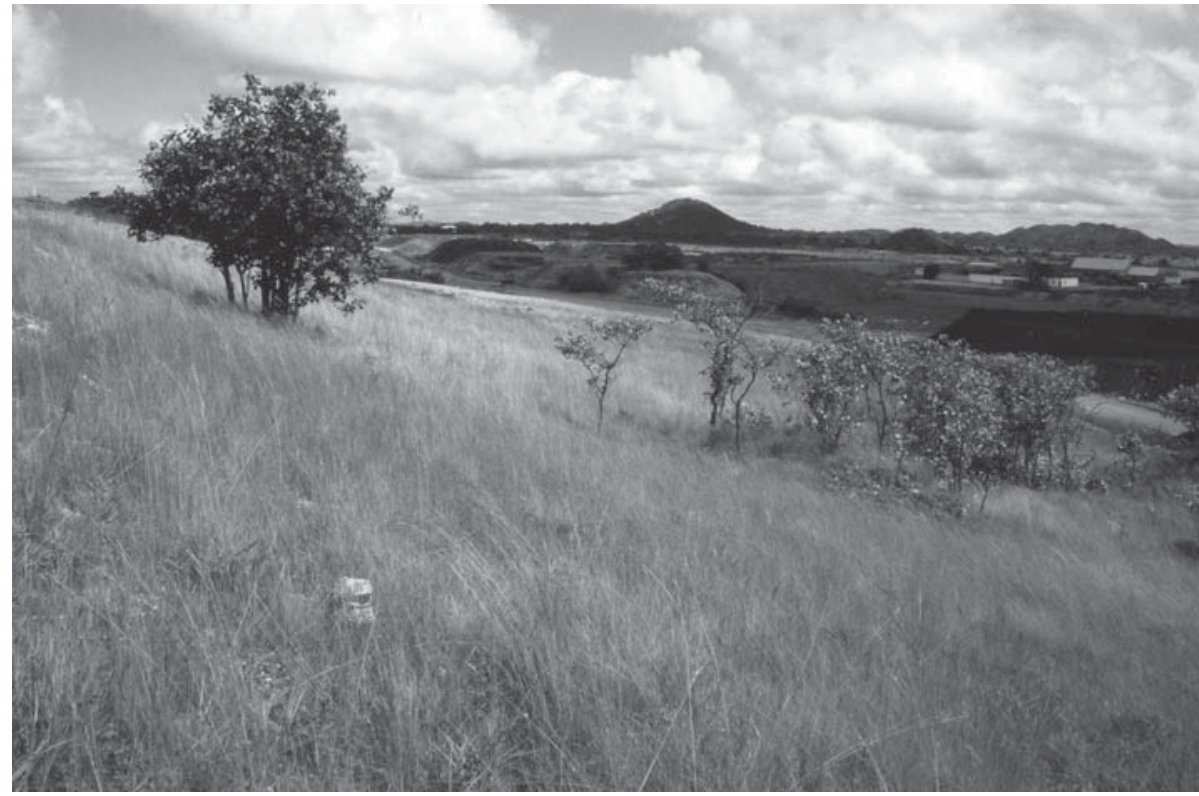

(a)

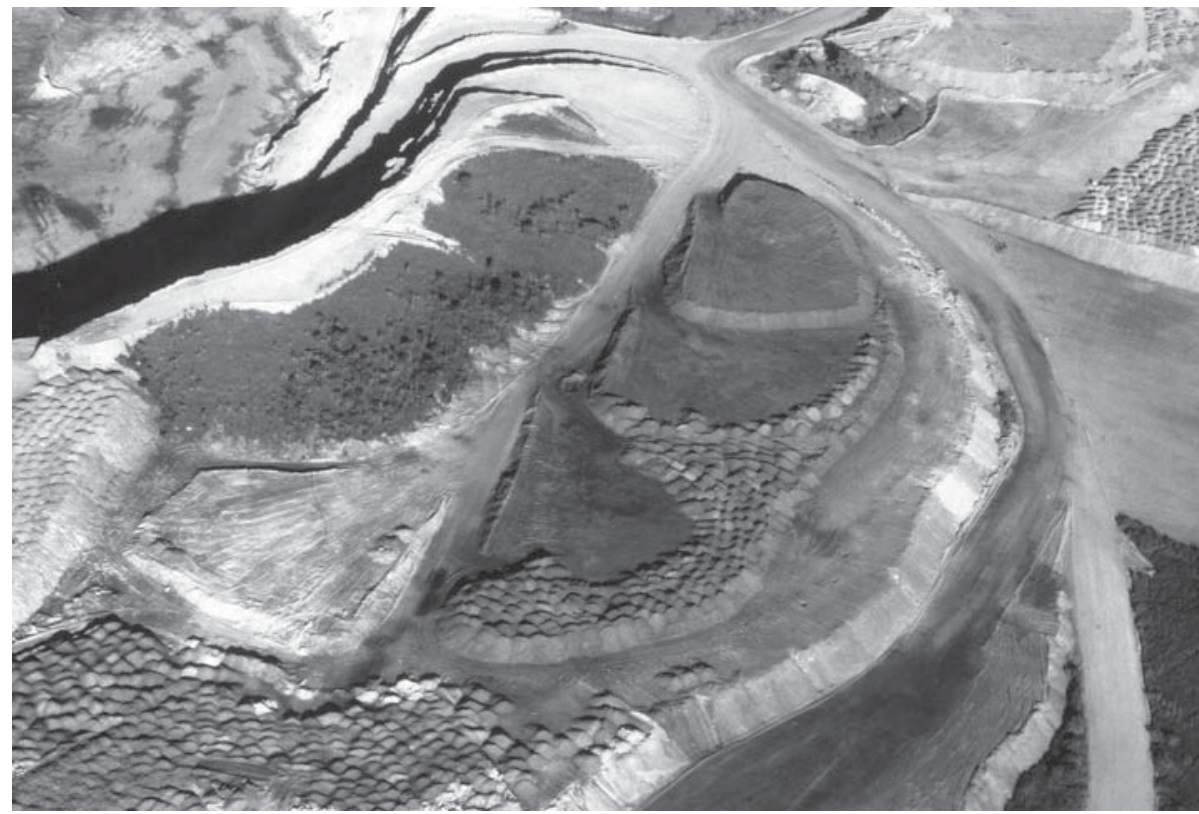

(b)

Figure 2.4. Luiswishi copper mine, Katanga. (a) Remnant metallophyte vegetation surrounded by active mining operations. (b) Aerial view of the mine site in 2007, showing the small conservation area. Photos: F. Malaisse. 
The flora and vegetation of Luiswishi had been studied previously (Malaisse et al. 1999). Seventy-one taxa were listed in 1997. A new survey took place in 2001 to prospect for further metallophytes and discovered a new, unpublished taxon of Chlorophytum (Antheriaceae). Further surveys took place in 2006 and 2007 , by which time only $10 \%$ of the site was unmined. These surveys confirmed the presence of 42 of the 71 taxa previously recorded, as well as 11 species reported for the first time. It is clear that recent mining activities have destroyed most of the metallophyte vegetation at this important mine site (Fig. 2.4a). Of the 29 species that have disappeared, three are of major concern; they were known from only two other sites (Étolie and Sokoroshe mines) where they are endangered. However, recently a small area of the site has been preserved and protected from mining (Fig. 2.4b). Unfortunately, this area does not support the new species. A similar study was made at Tilwezembe, near the Lupula river where Malaisse and co-workers have been allowed to carry out botanical surveys in two different seasons. A total diversity of 73 higher plants has been recorded there. As at Luiswishi, mining activities have progressed rapidly and only a very reduced rocky area is conserved.

Our knowledge of natural revegetation processes at Cu-Co metalliferous mine workings in Katanga has only received preliminary study (Leteinturier et al. 1999). A set of nine ecological conditions has been suggested, based upon both the heavy-metal content of soil and its state of hydration. Taxa have been identified for each condition recognised, with one indicator species suggested. Research on the cultivation of these taxa is urgently needed in order to recommend appropriate revegetation strategies to sustain the metallophyte flora. One very positive initiative commenced in 2004 through a $\mathrm{PhD}$ programme at Lubumbashi University established in cooperation with Belgian universities (Brussels and Gembloux). It is designed to produce Congolese specialists in Katangan phytogeochemistry able to take over conservation programmes in the mining companies.

\section{Status of metallophytes in Latin America}

Knowledge of tropical and sub-tropical metallophyte distribution and ecology lies far behind that for temperate taxa, especially those in Europe. Few metaltolerant and metal hyperaccumulator plants have been reported in Latin America in comparison to other areas of the world, such as North America, Oceania, Asia, Europe and Africa (Brooks 1998). A total of approximately 172 plant species have been described in the literature for the Region as either metal-tolerant (30 species) or hyperaccumulators (142 species; Ginocchio \& Baker 2004), a very low number when compared to the high plant diversity described for the Region (Cincotta et al. 2000). Most of these plants are nickeltolerant and hyperaccumulator plants (89\%) as most studies pertain to serpentine areas in Brazil, Cuba, Dominican Republic and Venezuela, followed 
by copper (5\%) and arsenic (3\%) (Baker \& Brooks 1988; Ginocchio \& Baker 2004). Investigations over ultramafic rocks in Argentina and Paraguay (Reeves \& Baker 2000) have also been performed but they have not revealed further metaltolerant plants.

Latin America is a potential area where metallophytes could be found, not only due to the high and unique plant diversity but also to the presence of a high number of ore deposits (e.g., gold, silver, copper, iron and lead) and metalenriched areas such as those near abandoned tailings dumps and metal smelters, due to historical mining operations under no environmental regulations. Many areas in Latin America are major centres of plant diversity, not only because of species-rich tropical forests but also because of many geographical areas where a diverse and unique endemic flora exists. For example, 8 of the 25 hotspot areas defined for their high biodiversity in the world are located in Latin America (Myers et al. 2000). However, this diversity is still poorly evaluated, studied and protected, including metallophytes. If a high and unique plant diversity has co-existed and evolved in ore-rich environments, it is reasonable to think that metallophytes may have evolved in the Region, and thus, it is necessary to start reconnaissance work, before possible extinction from metal mining activities, notably strip-mining. Current information on metallophytes in the Region has derived from three main sources: scientific research performed by botanists and plant ecologists, geobotanical surveys performed by geologists and mine engineers and traditional knowledge from small-scale artesanal miners.

\section{Information from scientific research}

Although scientific research on metallophytes in the Region is limited, a number of plants have been described in the literature (see review: Ginocchio \& Baker 2004). Recent evidence indicates that three As-hyperaccumulating plants (Bidens cynapiifolia (Asteraceae), Paspalum racemosum and P. tuberosum (Poaceae)) and one possible Cu-tolerant plant (Bidens cynapiifolia) grow near a copper mine in the northern Peruvian Andes (Bech et al. 1997); 11 Ni-hyperaccumulating plants in the serpentine flora of the Goiás State in Brazil (Brooks et al. 1990, 1992b); $106 \mathrm{Ni}$ - and one Cu-hyperaccumulating plants in serpentine soils of Cuba (Brooks et al. 1990, 1992b). One Se-hyperaccumulating tree ('monkey nut tree', Lecythis ollaria (Lecythidaceae)) has been reported in Venezuela (Aronow \& Kerdel-Vegas 1965); three Zn-tolerant plants and some possible Pb- and As-tolerant plants have been found in Ecuador (Bech et al. 2001, 2002); and some Cu-tolerant ecotypes of wide-spread plant species have been discovered in Chile near a copper smelter (Mimulus luteus var. variegatus (Scrophulariaceae)) (Ginocchio et al. 2002), on tailings sands (Mullinum spinosum (Apiaceae)) (Bech et al. 2002) and near copper mines (Nolana divaricata (Solanaceae)) (Ruelle 1995), Cenchrus echinatus (Poaceae) and Erigeron berterianum (Asteraceae) (Bech et al. 2002). Investigations over ultramafic rocks in Argentina and Paraguay (Reeves \& Baker 2000) and heavily metal-polluted 
soils near a copper smelter in central Chile (Ginocchio 1997, 1999, 2000) have also been performed by local and international scientists but they have not revealed further metal-tolerant plants.

In the last decade, however, increasing research has occurred in the Region in order to identify metallophytes. For example, scientific explorations performed in two different areas of northcentral Chile have recently resulted in an important number of new descriptions of copper-tolerant plants native and endemic to the country. The first study was carried out in a large area of northcentral Chile that has a semi-arid Mediterranean climate type (the Coquimbo Region). Due to historic copper/gold mining a large number, 395 (SERNAGEOMIN 1989, 1990), of abandoned tailings storage facilities (TSF) are scattered throughout the area. Furthermore, metal-polluted soils and natural mineralised areas are also quite common inside the area. The results showed that 76 abandoned TSFs have been colonised by 106 local plants, 71\% being native and endemic to Chile. In laboratory tests, 33 species were found to be copper-tolerant. A second study was performed in the Yerba Loca Natural Sanctuary (YLNS), a well-known high-alpine valley in central Chile, for its historic surface water anomalies. The YLNS $\left(33^{\circ} \mathrm{S} 60^{\circ} \mathrm{W}\right)$ is located c. $60 \mathrm{~km}$ east of the city of Santiago and west from the south edge of the Río Blanco-Los Bronces-Yerba Loca Cu-Mo deposit. A large porphyry $\mathrm{Cu}$ deposit $\left(>40 \mathrm{~km}^{2}\right)$ with secondary formation of tourmaline and Cu-Zn-Mo sulphides thus exists at high elevations of the basin. Mineral deposits have long influenced surface water quality of streams in the area which broadly differs from dilute waters described for the high Andes in central Chile, particularly in terms of $\mathrm{pH}$, sulphate content and mineral concentrations. For example, the main stream along the YLNS has acidic $\mathrm{pH}(4.1-5.3)$ and high sulphate (>150 $\mathrm{mg} \mathrm{L}^{-1}$ ) and metal content waters (3.6-9.1 $\mathrm{mg} \mathrm{Cu} \mathrm{L}^{-1}$ and $0.2 \mathrm{mg} \mathrm{Zn} \mathrm{L} \mathrm{L}^{-1}$ ). These marked gradients in surface water chemistry may have an important role in structuring plant communities at the YLNS, particularly in meadows, as acidic and metal-rich waters are highly toxic to most plant species, thus resulting in tertiary heavy-metal vegetation. In harsh water quality environments only a limited suite of species is adapted to survive and reproduce on highalpine meadows at the YLNS. Indeed, Festuca purpurascens (Poaceae), Gaultheria caespitosa (Ericaceae), Calamagrostis chrysostachya (Poaceae) and Empetrum rubrum (Empetraceae) are abundant in habitats with acidic and metal-rich waters, while Carex macloviana (Cyperaceae), Patosia clandestine (Juncaceae) and Erigeron andicola (Asteraceae) are abundant in habitats with diluted waters. In the YLNS, a total of 30 potential metallophytes have already been identified but further laboratory testing for metal tolerance is under way.

\section{Information from geobotanical surveys}

Large-scale mining in Latin America has employed traditional methods of exploration for minerals based on geology (rock colouration), radiometrics, 
photogeology, thermal analysis, geochemistry and satellite imaging. Thus geobotanical methods of mineral exploration, concerned with the detection of subsurface mineralisation by an interpretation of its vegetative cover or 'indicator plants' (Brooks 1998) are rarely reported in the literature of the Region. Two of the few geobotanical surveys published in the Region are those of Viladevall et al. (1994) in Bolivia and Fernández-Turiel et al. (1994) in Argentina. Viladevall et al. (1994) suggested that Baccharis incarum (Asteraceae) and Fabiana densa (Solanaceae) are good shrubs or 'tholas' to be used as regional metal indicator plants in geobotanical surveys for Au, As, Sb and other metals in the altiplanic areas of Bolivia, as their leaves are indicators of the metal contents in the subsoil. In the Puna belt of Argentina, however, these species grow on many soil types (Bonaventura et al. 1995). Although these plants cannot be classified as hyperaccumulator plants as they only reached a maximum of $540 \mathrm{mg} \mathrm{kg}^{-1} \mathrm{Sb}$ in their leaves, a value below the criteria of $>1000 \mathrm{mg} \mathrm{kg}^{-1}$ for Sb-hyperaccumulating plants, they may have metallophyte status. FernándezTuriel et al. (1994) suggested that Prosopis alba (Mimosaceae) and Larrea divaricata (Caesalpiniaceae) growing near an old smelter in the Sierra Pampeanas in Argentina had two to six times more $\mathrm{Sr}, \mathrm{Cd}, \mathrm{Bi}, \mathrm{Zn}, \mathrm{Ni}, \mathrm{Li}$ and $\mathrm{Cu}$ than the same plants growing on unpolluted soils. They reported that all the shrubs studied had the same pattern of metal accumulation in above-ground structures as metal levels increased in soils, with the exception of P. alba and P. nigra which accumulated more $\mathrm{Zn}$ than the other plants growing in the same soils (700 vs. $200 \mathrm{mg} \mathrm{kg}^{-1} \mathrm{Zn}$ in ash), a characteristic of metallophytes. Furthermore, with the exception of serpentine floras described in Cuba and Brazil, there are no reports of unusual locations where metallophytes dominate.

\section{Information from artesanal small-scale miners}

Small-scale mining activities reveal additional, albeit unconfirmed, data on metal ore indicating plants, as artesanal miners searched for metal ores using simple biogeochemical methods of exploration based on rock colouration and the associated plants. For example, when the Chilean endemic shrub Gymnophyton robustum (Apiaceae) grows on green-coloured rocks, miners are sure that a copper ore is present in the subsoil. Although this information has not been gathered extensively and reported formally in the literature, it may represent an important source of information to commence a search for further metallophytes, as artesanal mining is common in the Region.

\section{Environmental threats from metal mining in Latin America}

A lack of environmental regulations in most countries of the Region until recent decades has allowed metal mining to result in serious and diverse environmental problems threatening local vegetation in general and metallophytes in particular. Although the situation has changed more recently due to 
the establishment of environmental laws and regulations in some countries, such as Peru and Chile, others have followed a tendency to review or relax the environmental standards governing mining to encourage investment, trade liberalization, technological change, cross-border merges and acquisitions, increase influence from large corporations and investor pressure (WWF International \& IUCN 1999). Despite these problems, some progress is being made at policy, regulatory and technical levels by Latin American governments, mining industries and international actions to protect biodiversity such as the Convention on Biological Biodiversity. Latin America has attracted the majority of the world's investments in mining and so new laws and regulations are not robust enough to prevent present and future threats to metallophytes that may be discovered in the Region, mainly due to habitat loss.

Five mining hotspots have been identified in the world in 1999, one being located in the Guyanan and Andean regions of Latin America and another at the Pacific Rim (WWF International \& IUCN 1999). Many are coincident with hotspots for biodiversity (Myers et al. 2000), and vegetation has already been affected by mining operations or is under heavy pressure by metal mining, particularly due to badly planned and managed mining operations. For example, it is interesting to note that many of the Chilean vascular plants, particularly perennial herbs and shrubs, especially metallophytes, have a very limited distributional range (Arroyo \& Cavieres 1997; Villagrán \& Hinojosa 1997), and thus they are highly vulnerable to extinction if present and future mining are not adequately regulated.

A major initiative by local scientists, governmental agencies and mining companies is needed to promote the determination of metallophytes that may exist in arid and semi-arid areas of Latin America through extensive geobotanical exploration, not only on mineralised areas but also on abandoned tailings dumps or other metal-enriched areas. Metallophytes are key resources for the minerals industry as they can be used for rehabilitation of mined areas and massive mine wastes (i.e., phytostabilisation), such as tailings storage facilities. Their proven and potential use in mine rehabilitation can help drive conservational efforts as they normally thrive on mine sites that are worked, thus improving environmental sustainability of the mining industry beyond the limited regulatory framework (Whiting et al. 2004; Ginocchio et al. 2007).

\section{Research initiatives}

Metallophytes are of proven special scientific interest, and metallophyte research is carried out at many universities and government research institutes worldwide. In Europe, collaborative research programmes have been facilitated by COST (Co-Opération Scientifique et Technologique) Action 837 ('Plant biotechnology for the decontamination of waters and sites contaminated by 
organic pollutants and metals'), COST Action 859 ('Phytotechnologies to promote sustainable land use and improve food safety of the EU'), by the Research and Development project PHYTAC ('Development of systems to improve phytoremediation of metal contaminated soils through improved phytoaccumulation') and by the EU Research Training Network METALHOME ('Molecular mechanisms of metal homeostasis in higher plants'), both within the EU Framework V programme. Other very active research centres are in the USA at, for example, Cornell and Purdue Universities, and USDA-ARS, and recently in China (Lou et al. 2004; Deng et al. 2007; Ke et al. 2007; Xiong et al. 2008). Almost all current research focuses on the biochemistry, physiology and genetics of mechanisms for metal adaptation, and on mycorrhizal symbioses, root-associated microbes and metal tolerance (Whiting et al. 2004), plant-animal interactions (Ernst 1987; Boyd \& Martens 1994; Pollard \& Baker 1997; Huitson \& Macnair 2003; Noret et al. 2007), phytoremediation (Baker et al. 2000; Chaney et al. 2000; van Ginneken et al. 2007; Wieshammer et al. 2007), aspects of the bioavailability of metals in soil and ecotoxicology predominantly in the context of risk assessment and regulatory and legislative aspects of soil contamination.

Causes of the rapid decline in the vitality of metallophyte vegetation are well-known for secondary and tertiary sites, as mentioned above. Science lacks coherent insight into the exact measures for its restoration. For conservation and restoration efforts it is important to set up programmes with experimental restoration measures with scientific research focused on the interaction of micro-organisms and metallophytes. Furthermore, research into the geographic distribution, ecological amplitude and niche differentiation of metallophytes, and the impact of ecological management and habitat alteration on metallophyte vegetation, is necessary to facilitate conservation and to develop and manage sites in the future.

Action towards conserving the global metallophyte resource base is imperative, because many species are under threat of extinction from the current quest for base metals and the mining boom. The extent of this unique resource, and its potential in future phytotechnologies is unknown (Whiting et al. 2004) but clearly represents a great asset in the care of the minerals industry. This has been identified as a priority area in the Mining, Minerals and Sustainable Development (MMSD) Project of the Global Mining Initiative (IEED 2002), but positive responses from the minerals industry have to date been slow. The potential importance of mine sites for biodiversity has, however, long been recognised (Johnson 1978; Smith 1979, Whiting et al. 2004; Batty 2005; Baker \& Whiting 2008), but guidelines for its conservation and management have only recently been formalized (ICMM 2006).

The European Heavy Metal Ecology Network (EHMEN) was started in 2006 to promote research collaboration and increased insight into the biodiversity, ecology and biogeochemistry of metallophyte vegetation in order to facilitate 
conservation efforts and restoration ecology in Europe. EHMEN has organised conferences and field visits, the first of which was held at Kelmis, Belgium, in 2006. Initiatives like this are also needed on a global scale to document and research this rich source of plant biodiversity and to document and conserve the important biotechnological metallophyte resources (Whiting et al. 2004; Baker \& Whiting 2008). The authors of this chapter strongly support the need for further biogeochemical exploration particularly in parts of the world other than those highlighted in this review, notably much of southeast Asia, and the establishment of a global database of metallophytes.

\section{Acknowledgements}

We dedicate this chapter to the memory of Professor Tony Bradshaw, FRS, a former President of the British Ecological Society and pioneer in metallophyte research and whose vision in recognising the nature and scale of evolutionary adaptation of plants in extreme habitats has led to the discipline of restoration ecology. He sadly passed away on 21 August 2008, during the preparation of this chapter.

\section{References}

Antonovics, J., Bradshaw, A.D. and Turner, R. G. (1971) Heavy metal tolerance in plants. Advances in Ecological Research 7, 1-85.

Aronow, L. and Kerdel-Vegas, F. (1965) Seleno-cystathionine, a pharmacologically active factor in the seeds of Lecythis ollaria. Nature 205, 1185-1186.

Arroyo, M.T. K. and Cavieres, L. (1997) The Mediterranean-type climate flora of central Chile. What do we know and how we can assure its protection. Noticiero de Biología 5, 48-55.

Assunção, A. G. L., Da Costa Martins, P., De Folter, S., Vooijs, R., Schat, H. and Aarts, M. G. M. (2001) Elevated expression of metal transporter genes in three accessions of the metal hyperaccumulator Thlaspi caerulescens. Plant, Cell and Environment 24, 217-226.

Baker, A.J. M. (1987) Metal tolerance. New Phytologist. 106 (Suppl.), 93-111.

Baker, A.J. M. and Brooks, R. R. (1988) Botanical exploration for minerals in the humid tropics. Journal of Biogeography. 15, 221-229.

Baker, A.J.M. and Brooks, R. R. (1989) Terrestrial higher plants that hyperaccumulate metallic elements - a review of their distribution, ecology and phytochemistry. Biorecovery 1, 81-126.

Baker, A. J. M. and Proctor, J. (1990) The influence of cadmium, copper, lead, and zinc on the distribution and evolution of metallophytes in the British Isles. Plant Systematics and Evolution 173, 91-108.

Baker, A.J. M. and Whiting, S. N. (2008) Metallophytes - a unique biodiversity and biotechnological resource in the care of the minerals industry. In: Proceedings of the Third International Seminar on Mine Closure, 14-17 October 2008, Johannesburg, South Africa. (eds. A. Fourie, M. Tibbett, I. Weiersbye and P. Dye), pp. 13-20. Australian Centre for Geomechanics, Nedlands, Western Australia

Baker, A. J. M., Brooks, R. R., Pease, A.J. and Malaisse, F. (1983) Studies on copper and cobalt tolerance in three closely related taxa within the genus Silene L. (Caryophyllaceae) from Zaïre. Plant and Soil 73, 377-385.

Baker, A.J. M., McGrath, S.P., Reeves, R.D. and Smith, J.A.C. (2000) Metal hyperaccumulator plants: a review of the ecology and physiology of a biological resource for phytoremediation of metal-polluted soils. 
In: Phytoremediation of Contaminated Soil and Water (eds. N. Terry and G.S. Bañuelos), pp. 85-107. Lewis/CRC Press Inc, Boca Raton.

Barnatt, J. and Penny, R. (2004) The Lead Legacy.

The Prospects for the Peak District's Lead Mining Heritage. Peak District National Park Authority; Buxton, UK.

Batty, L.C. (2005) The potential importance of mine sites for biodiversity. Mine Water and the Environment 24, 101-103.

Baumbach, H. (2005) Genetic differentiation of Central European heavy metal ecotypes of Silene vulgaris, Minuartia verna and Armeria maritima in consideration of biogeographical, mining historical and physiological aspects (in German). Dissertationes Botanicae 398, 1-128.

Baumbach, H. and Hellwig, F. H. (2007) Genetic differentiation of metallicolous and non-metallicolous Armeria maritima (Mill.) Willd. taxa (Plumbaginaceae) in Central Europe. Plant Systematics and Evolution 269, 245-258.

Baumbach, H. and Schubert, R. (2008) New taxonomic perception of the characteristic species of the heavy metal vegetation and possible consequences for nature conservation of metal-enriched sites (in German). Feddes Repertorium 119, 543-555.

Baumbach, H., Volkmann, H. K. M. and Wolkersdorfer, C. (2007) Heavy metal vegetation on smelter dust at the Weinberg near Hettstedt-Burgörner (Mansfelder Region). Results of centuries of emission and a demand for nature conservation (in German). Hercynia N. F. 14, 87-109.

Bech, J., Poschenrieder, C., Llugany, M. et al. (1997) Arsenic and heavy metal contamination of soil and vegetation around a copper mine in Northern Peru. The Science of the Total Environment 203, 83-91.

Bech, J., Poschenrieder, C., Barceló, J. and Lansac, A. (2001) Heavy metal and arsenic accumulation in selected plants species around a silver mine in Ecuador. Proceedings of the 6th International Conference on the
Biogeochemistry of Trace Elements (ICOBTE), Guelph, Canada. p. 393.

Bech, J., Poschenrieder, C., Barceló, J. and Lansac, A. (2002) Plants from mine spoils in the South American area as potential sources of germplasm for phytoremediation technologies. Acta Biotechnologica 22, 5-11.

Becker, T., Brändel, M. and Dierschke, H. (2007) Dry grassland on heavy metal-enriched and non-metal-enriched soils of the Bottendorf hills in Thuringia (in German). Tuexenia 27, 255-285.

Bert, V., Macnair, M.R., De Laguerie, F., Saumitou-Laprade, P. and Petit, D. (2000) Zinc tolerance and accumulation in metallicolous and nonmetallicolous populations of Arabidopsis halleri (Brassicaceae). New Phytologist 146, 225-233.

Bert, V., Meerts, P., Saumitou-Laprade, P., Salis, P., Gruber, W. and Verbruggen, N. (2003) Genetic basis of Cd tolerance and hyperaccumulation in Arabidopsis halleri. Plant and Soil 249, 9-18.

Bizoux, J.P. and Mahy, G. (2007) Withinpopulation genetic structure and clonal diversity of a threatended endemic metallophyte, Viola calaminaria (Violaceae). American Journal of Botany 94, 887-895.

Bizoux, J.P., Brevers, F., Meerts, P., Graitson, E. and Mahy, G. (2004) Ecology and conservation of Belgian populations of Viola calaminaria, a metallophyte with a restricted geographical distribution. Belgian Journal of Botany 137, 91-104.

Bleeker, P. M., Hakvoort, H.W.J., Bliek, M., Souer, E. and Schat, H. (2006) Enhanced arsenate reduction by a CDC25-like tyrosine phosphatase explains increased phytochelatin accumulation in arsenate-tolerant Holcus lanatus. Plant Journal 45, 917-929.

Bonaventura, S. M., Tecchi, R. and Vignata, D. (1995) The vegetation of the Puna Belt at laguna de Pozuelos Biosphere Reserve in northwest Argentina. Plant Ecology 119, 23-31.

Boyd, R. S. and Martens, S. N. (1994) Nickel hyperaccumulated by Thlaspi montanum var. 
montanum is acutely toxic to an insect herbivore. Oikos 70, 21-25.

Brej, T. (1998) Heavy metal tolerance in Agropyron repens (L.) P. Beauv. populations from the Legnica copper smelter area, Lower Silesia. Acta Societatis Botanicorum Poloniae 67, 325-333.

Bröker, W. (1963) Genetic-physiological investigations of zinc tolerance in Silene inflata Sm. (in German). Flora 153, 122-156.

Brooks, R.R. (1998) Geobotany and hyperaccumulators. In: Plants that Hyperaccumulate Heavy Metals: their Role in Phytoremediation, Microbiology, Archaeology, Mineral Exploration and Phytomining (ed. R. R. Brooks), pp. 55-94. CAB International, Oxon, UK.

Brooks, R. R. and Crooks, R.R. (1979) Studies on the uptake of heavy metals by the Scandinavian 'kisplanten' Lychnis alpina and Silene dioica. Plant and Soil 54, 491-496.

Brooks, R. R., Baker, A.J.M. and Malaisse, F. (1992a) Copper flowers. National Geographic Research and Exploration 8, 338-351.

Brooks, R. R., Malaisse, F. and Empain, A. (1985) The Heavy Metal-tolerant Flora of Southcentral Africa. A Multidisciplinary Approach. A. A. Balkema, Rotterdam.

Brooks, R.R., Naidu, S.M., Malaisse, F. and Lee, J. (1987) The elemental content of metallophytes from the copper/cobalt deposits of Central Africa. Bulletin de la Société Royale de Botanique de Belgique 119, 179-191.

Brooks, R. R., Reeves, R.D. and Baker, A.J. M. (1992b) The serpentine vegetation of the Goiás State, Brazil. In: The Vegetation of Ultramafic (Serpentine) Soils (eds. A. J. M. Baker, J. Proctor and R. D. Reeves), pp. 67-81. Intercept Ltd, Andover, UK.

Brooks, R. R., Reeves, R.D., Baker, A.J. M., Rizzo, J.A. and Díaz-Ferreira, H. (1990) The Brazilian serpentine plant expedition (BRASPEX), 1988. National Geographic Research 6, 205-219.

Brown, G. (2001) The heavy-metal vegetation of north-western mainland Europe. Botanische Jahrbücher für Systematik 123, 63-110.
Chaney, R. L., Li, Y. M., Brown, S. L. et al. (2000) Improving metal hyperaccumulator wild plants to develop commercial phytoextraction systems; approaches and progress. In: Phytoremediation of Contaminated Soils and Water (eds. N. Terry and G.S. Bañuelos), pp. 131-160. CRC Press, Boca Raton.

Chardonnens, A. N., Ten Bookum, W.M., Vellinga, S., Schat, H., Verkleij, J.A.C. and Ernst, W.H. O. (1999) Allocation patterns of zinc and cadmium in heavy metal tolerant and sensistive Silene vulgaris. Journal of Plant Physiology 155, 778-787.

Choo, F., Paton, A. and Brooks, R. R. (1996) A re-evaluation of Haumaniastrum species as geobotanical indicators of copper and cobalt. Journal of Geochemical Exploration 56, 37-45.

Cincotta, R. P., Wisnewski, J. and Engelman, R. (2000) Human population in the biodiversity hotspots. Nature 404, 990-992.

Clemens, S. (2001) Molecular mechanisms of plant metal tolerance and homeostasis. Planta 212, 475-486.

Clemens, S., Palmgren, M. G. and Krämer, U. (2002) A long way ahead: understanding and engineering plant metal accumulation. Trends in Plants Science 7, 309-317.

Corley, M. F. V. and Perry, A. R. (1985) Scopelophila cataractae (Mitt.) Broth. in South Wales, new to Europe. Journal of Bryology 13, 323-328.

Dahmani-Müller, H., van Oort, E., Gélic, B. and Balabane, M. (2000) Strategies of heavy metal uptake by three plant species growing near a smelter site. Environmental Pollution 109, 231-238.

Davies, B. E. and Roberts, L.J. (1978) The distribution of heavy metal contaminated soils in north-east Clwyd, Wales. Water, Air and Soil Pollution 9, 507-518.

Deng, D. M., Shu, W.S., Zhang, J. et al. (2007) Zinc and cadmium accumulation and tolerance in populations of Sedum alfredii. Environmental Pollution 147, 381-386.

De Plaen, G., Malaisse, F. and Brooks, R. R. (1982) The copper flowers of Central Africa and 
their significance for prospecting and archaeology. Endeavour, NS 6, 72-77.

Dierschke, H. and Becker, T. (2008) The heavy metal vegetation in the Harz - arrangement, ecological conditions, and syntaxonomic classification (in German). Tuexenia $\mathbf{2 8}$, 185-227.

Dudley, T. R. (1986) A new nickelophilous species of Alyssum (Cruciferae) from Portugal, Alyssum pintodasilvae. Feddes Repertorium 97, 139-142.

Dueck, T. A., Ernst, W.H.O., Faber, J. and Pasman, F. (1984) Heavy metal emission and genetic constitution of plant populations in the vicinity of two metal emission sources. Angewandte Botanik 58, 47-59.

Duvigneaud, P. (1958) The vegetation of Katanga and its metalliferous soils (in French). Bulletin de la Société Royale de Botanique de Belgique 90, 127-286.

Duvigneaud, P. (1959) Cobaltophytes in Upper Katanga (in French). Bulletin de la Société Royale de Botanique de Belgique 91, 111-134.

Duvigneaud, P. and Denaeyer-De Smet, S. (1963) Copper and the vegetation of Katanga (in French). Bulletin de la Société Royale de Botanique de Belgique 96, 92-231.

Ernst, W.H.O. (1964) Ecological and phytosociological investigations of heavy metal plant communities in Central Europe and the Alpine Mountains (in German). Unpublished PhD Thesis, Westfälische Wilhelms-Universität Münster, Germany.

Ernst, W. H. O (1972) Ecophysiological studies on heavy metal plants in South Central Africa. Kirkia 8, 125-145.

Ernst, W. H. O. (1974) Heavy Metal Vegetation of the World (in German). Geobotanica Selecta, Band V. Gustav Fischer Verlag, Stuttgart.

Ernst, W.H. O (1976) Violetea calaminariae. In: Prodomus of the European Plant Communities Vol. 3 (ed. R. Tüxen), pp. 1-132. J. Cramer, Vaduz.

Ernst, W.H. O. (1978) Ecological borderline between Violetum calaminariae and GentianoKoelerietum (in German). Berichte der Deutschen Botanischen Gesellschaft 89, 381-390.
Ernst, W.H. O. (1987) Population differentiation in grassland vegetation. In: Disturbance in Grasslands (eds. J. Van Andel, J. Bakker and R.W. Snaydon), pp. 213-236. Junk Publishers, Dordrecht.

Ernst, W.H. O. (1990) Mine vegetation in Europe. In: Heavy Metal Tolerance in Plants: Evolutionary Aspects (ed. A.J. Shaw), pp. 21-37. CRC Press, Boca Raton.

Ernst, W.H. O. (2000) Evolution of metal hyperaccumulation and the phytoremediation hype. New Phytologist 146, 357-358.

Ernst, W.H. O. (2006) Evolution of metal tolerance in higher plants. Forest, Snow Landscape Research 80, 251-274.

Ernst, W.H.O. and Nelissen H.J. M. (2000) Life-cycle phases of a zinc- and cadmium-resistant ecotype of Silene vulgaris in risk assessment of polymetallic soils. Environmental Pollution 107, 329-338.

Ernst, W.H.O., Knolle, F., Kratz, S. and Schnug, E. (2004) Aspects of ecotoxicology of heavy metals in the Harz region - a guided excursion. Landbauforschung Völkenrode 54, 53-71.

Ernst, W.H.O., Krauss, G.J., Verkleij, J. A.C. and Wesenberg, D. (2008) Interaction of heavy metals with the sulphur metabolism in angiosperms from an ecological point of view. Plant, Cell and Environment 31, 123-143.

Ernst, W.H. O., Verkleij, J.A.C. and Schat, H. (1992) Metal tolerance in plants. Acta Botanica Neerlandica 41, 229-248.

European Convention on the Protection of the Archaeological Heritage (Revised) Valetta, 16.I. 1992, Council of Europe.

EU Habitats Directive Annex I (Fauna-Flora-Habitat), 1992, European Union.

EUNIS (European Environment Agency) database website at: http://eunis.eea.europa. eu/habitats-factsheet.jsp? $\mathrm{tab}=0$ \&idHabitat $=10113$.

Fernández-Turiel, J. L., Rossi, J. N., Aceñolaza, P. et al. (1994) Environmental issues of biogeochemical studies at the Famantina range, La Rioja, Argentina (in Spanish). 
Proceedings $7^{\circ}$ Congreso Geológico Chileno, Concepción, Chile. pp. 613-617.

Ginocchio, R. (1997) Applicability of time-spatial vegetation distribution models to terrestrial polluted ecosystems (in Spanish). Unpublished PhD Thesis, P. Universidad Católica de Chile, Santiago, Chile.

Ginocchio, R. (1999) Copper tolerance testing on plant species growing near a copper smelter in central Chile. Proceedings of the 5th International Conference on the Biogeochemistry of Trace Elements (ICOBTE), Vienna, Austria. pp. 1156-1157.

Ginocchio, R. (2000) Effects of a copper smelter on a grassland community in the Puchuncaví Valley, Chile. Chemosphere 41, 15-23.

Ginocchio, R. and Baker, A.J. M. (2004) Metallophytes in Latin America: a remarkable biological genetic resource scarcely known and studied in the region. Revista Chilena de Historia Natural 77, 185-194.

Ginocchio, R., Toro, I., Schnepf, D. and Macnair, M. R. (2002) Copper tolerance in populations of Mimulus luteus var. variegatus exposed and non-exposed to copper pollution. Geochemistry: Exploration, Environment, Analysis

2, 151-156.

Ginocchio, R., Santibáñez, C., León-Lobos, P., Brown, S. and Baker, A.J. M. (2007) Sustainable rehabilitation of copper mine tailings in Chile through phytostabilization: more than plants. Proceedings of the 2nd International Conference Mine Closure 2007, Santiago, Chile.

Graitson, E., Melin, E. and Goffin, M. (2003) Listing and characterisation of calaminarian sites in the Walloon region (in French). Société Publique d'Aide à la Qualité de l'Environnement G.I.R.E.A.: Université de Liège.

Griffioen, W.A.J., Ietswaart, J.H. and Ernst, W.H. O. (1994) Mycorrhizal infection of Agrostis capillaris on a copper-contaminated soil. Plant and Soil 158, 83-89.

Hammond, J.P., Bowen, H.C., White, J.P. et al. (2006) A comparison of the Thlaspi caerulescens and Thlaspi arvense shoot transcriptomes. New Phytologist 170, 239-260.

Hanikenne, M., Talke, I. N., Haydon, M.J. et al. (2008) Evolution of metal hyperaccumulation required cis-regulatory changes and triplication of HMA4. Nature 453, 391-395.

Hildebrandt, U., Hoef-Emden, K., Backhausen, S. et al. (2006) The rare, endemic zinc violets of Central Europe originate from Viola lutea Huds. Plant Systematics and Evolution 257, 205-222.

Hildebrandt, U., Kaldorf, M. and Bothe, H. (1999) The zinc violet and its colonisation by arbuscular mycorrhizal fungi. Journal of Plant Physiology 154, 709-717.

Huitson, S. B. and Macnair, M. R. (2003) Does zinc protect the zinc hyperaccumulator Arabidopsis halleri from herbivory by snails? New Phytologist 159, 453-459.

International Council on Mining and Metals (ICMM). (2006) Good Practice Guidance for Mining and Biodiversity. ICMM, London. $142 \mathrm{p}$.

International Institute for Environment and Development (IEED) and World Business Council for Sustainable Development (WBCSD). (2002) Breaking New Ground: Mining, Minerals and Sustainable Development (Report of the MMSD Project). Earthscan, London. $441 \mathrm{pp}$.

Joint Nature Conservation Committee (JNCC). (2002) Habitat account - natural and semi-natural grassland formation. 6130 Calaminarian grasslands of the Violetalia calaminariae. http//www.jncc.gov.uk/ ProtectedSites/SACselection/habitat.

Johnson, M. S. (1978) Land reclamation and the botanical significance of some former mining and manufacturing sites in Britain. Environmental Conservation 5, 223-228.

Kakes, P. (1980) Genecological Investigations on Zinc Plants. Unpublished PhD Thesis, Universiteit van Amsterdam, Amsterdam.

Ke, W., Xiong, Z.T., Chen, S. and Chen, J. (2007) Effects of copper and mineral nutrition on growth, copper accumulation and mineral element uptake in two Rumex japonicus populations from a copper mine and an 
uncontaminated field site. Environmental and Experimental Botany 59, 59-67.

Keulartz, J. (2005) Operating at the Borderline. A Pragmatic View on Nature and Environment (in Dutch). Damon, Budel, the Netherlands.

Klein, M. and Niemann, H. (2007) After the flood comes mud removal. Hannoversche Allgemeine Zeitung, 24 August 2007.

Koch, M., Mummenhoff, K. and Hurka, H. (1998) Systematics and evolutionary history of heavy metal tolerant Thlaspi caerulescens in Western Europe - evidence from genetic studies based on isozyme analysis. Biochemical Systematics and Ecology 26, 823-828.

Krämer, U., Cotter-Howells, J. D., Charnock, J. M., Baker, A. J. M. and Smith, J.A.C. (1996) Free histidine as a metal chelator in plants that accumulate nickel. Nature 379, 635-638.

Kurris, F. and Pagnier, J. (1925) Botanical-chemical investigation of the zinc vegetation at Epen (in Dutch). Natuurhistorisch Maandblad 14, 86-89.

Lambinon, J. and Auquier, P. (1963) Flora and vegetation of calaminarian soils in the northern Walloon region and the western Rhineland. Chorological types and ecological groups (in French). Natura Mosana 16, 113-130.

Lenders, H.J. R., Leuven, R. S. E.W., Nienhuis, P.H. and Schoof, D.J.W. (1997) Nature Management and Development (in Dutch). Boom, Meppel.

Leteinturier, B. (2002) Evaluation of the phytocenotic potential of the Southerncentral African copper outcrops with a view to phytoremediation of sites polluted by mining activity (in French). Unpublished PhD Thesis, Agricultural University Gembloux, Belgium.

Leteinturier, B. and Malaisse, F. (2002) On the tracks of botanical collectors on copper outcrops of South Central Africa (in French). Systematics and Geography of Plants 71, 133-163.

Leteinturier, B., Baker, A. J.M. and Malaisse, F. (1999) Early stages of natural revegetation of metalliferous mine workings in South
Central Africa: a preliminary survey.

Biotechnologie, Agronomie, Société et Environment 3, 28-41.

Libbert, W. (1930) The vegetation of the Fallstein region (in German). Beihefte zu den Jahresberichten der Naturhistorischen Gesellschaft zu Hannover 2, 1-66.

Lombi, E., Tearall, K. L., Howarth, J. R., Zhao, F. J., Hawkesford, M.J. and McGrath, S.P. (2002) Influence of iron status on cadmium and zinc uptake by different ecotypes of the hyperaccumulator Thlaspi caerulescens. Plant Physiology 128, 1359-1367.

Lou, L. Q., Shen, Z.G. and Li, X.D. (2004) The copper tolerance mechanisms of Elsholtzia haichowensis, a plant from copper-enriched soils. Environmental and Experimental Botany 51, 111-120.

Macklin, M. G. and Smith, R. S. (1990) Historic riparian vegetation development and alluvial metallophyte plant communities in the Tyne Basin, North-east England. In: Vegetation and Erosion (ed. J. B. Thornes), pp. 239-256. John Wiley \& Sons, Chichester, UK.

Macnair, M. R. and Cumbes, Q. (1987) Evidence that arsenic tolerance in Holcus lanatus L. is caused by an altered phosphate uptake system. New Phytologist 107, 387-394.

Macnair, M.R., Smith, S.E. and Cumbes, Q.J. (1993) The heritability and distribution of variation in degree of copper tolerance in Mimulus guttatus at Copperopolis, California. Heredity 71, 445-455.

MAGS (1975) Environmental problems caused by heavy metals in the region of Stolberg (in German). Ministerium für Arbeits, Gesundheit und Soziales des Landes Nordrhein-Westfalen, Düsseldorf.

Malaisse, F. and Bamps, P. (2005) Basanthe kisimbae (Passifloracerae), a new species in Congo-Kinshasa. Systematics and Geography of Plants 75, 263-265.

Malaisse, F., Baker, A. J. M. and Ruelle, S. (1999) Diversity of plant communities and leaf heavy metal content at Luiswishi copper/ cobalt mineralization, Upper Katanga, 
Dem. Rep. Congo. Biotechnologie, Agronomie, Société et Environnement 3, 104-114.

Malaisse, F., Colonval-Elenkov, E. and Brooks, R.R. (1983) Studies on copper and cobalt tolerance in three closely-related taxa within the genus Silene L. (Caryophyllaceae) from Zaïre. Plant Systematics and Evolution 142, 207-221.

Mengoni, A., Gonnelli, C., Hakvoort, H.W.J. et al. (2003) Evolution of copper-tolerance and increased expression of a $2 \mathrm{~b}$-type metallothionein gene in Silene paradoxa L. populations. Plant and Soil 257, 451-457.

Myers, N. R. A., Mittermeier, R. A., Mittermeier, C. G., da Fonseca, G.A.B. and Kent, J. (2000) Biodiversity hotspots for conservation priorities. Nature 403, 853-858.

Nordal, I., Haraldson, K. B., Ergon, A. and Eriksen, A. (1999) Copper resistance and genetic diversity in Lychnis alpina (Caryophyllaceae) populations on mining sites. Folia Geobotanica 34, 471-481.

Noret, N., Meerts, P., Vanhaelen, M., Dos Santos, A. and Escarré, J. (2007) Do metal-rich plants deter herbivores? A field test of the defence hypothesis. Oikos 152, 92-100.

Olivieri, I. and Vitalis, R. (2001) Biology of extinctions (in French). Médecines Science 17, 63-69.

Pardey, A. (2002) Nature conservation of heavy metal sites. A survey of the present situation in Germany, Belgium and the Netherlands (in German). Naturschutz und Landschaftsplanung 34, 145-151.

Pardey, A., Kalkkuhl, R., Heibel, E. and Haese, U. (1999) Concept for the conservation of heavy metal vegetation (in German). Landesanstalt für Ökologie, Bodenordnung und Forsten/Landesamt fur Agrarordnung Nordrhein-Westfalen. LÖBF Schriftenreihe 16, 1-272.

Pawlowska, T.E., Blaszkowski, J. and Rühling, A. (1996) The mycorrhizal status of plants colonizing a calamine spoil mound in southern Poland. Mycorrhiza 6, 499-505.

Pollard, A.J. and Baker, A.J. M. (1997) Deterrence of herbivory by zinc hyperaccumulation in Thlaspi caerulescens (Brassicaceae). New Phytologist 135, 655-658.

Prat, S. (1934) The heredity of copper resistance (in German). Berichte der Deutschen Botanischen Gesellschaft 52, 65-67.

Punz, W. and Mucina, L. (1997) Vegetation on anthropogenic metalliferous soils in the Eastern Alps. Folia Geobotanica 32, 283-295.

Raskin, R. (2003) Can heavy metal vegetation be restored? (in German). Mitteilungen der Landesanstalt für Ökologie, Bodenordnung und Forsten 3, 18-21.

Reeves, R. D. and Baker, A.J. M. (2000) Metalaccumulating plants. In: Phytoremediation of Toxic Metals: Using Plants to Clean Up the Environment (eds. I. Raskin and B.D. Ensley), pp. 193-229. John Wiley \& Sons, New York.

Regvar, M., Vogel, K., Irgel, N. et al. (2003) Colonisation of pennycress (Thlaspi sp.) of the Brassicaceae by arbuscular mycorrhizal fungi. Journal of Plant Physiology 160, 615-626.

Robyns, W. (1932) Plant growth and flora on the copper-enriched soils in Upper Katanga (in Dutch). Natuurwetenschappelijk Tijdschrift 14, 101-107.

Robyns, A. (1995) Passifloraceae. Flora of Central Africa (Zaïre, Rwanda, Burundi) Spermatophyta (in French). Jardin Botanique national de Belgique, Meise, Belgium. 75 pp.

Rodwell, J. S., Morgan, V., Jefferies, R. G. and Moss, D. (2007) The European Context of the British Lowland Grassland. JNCC No. 349, Chapter 7. Metallophyte Vegetation. Joint Nature Conservation Committee, Peterborough, UK.

Ruelle, S. (1995) A study of metal pollution at the Paposo site (II Region, Chile) (in French). Travail de Fin d'Etudes 'Ingénieur Agronome, Faculté Universitaire des Sciences Agronomiques de Gembloux, Belgium. Schat, H., Sharma, S. S. and Vooijs, R. (1997) Heavy metal-induced accumulation of free proline in a metal-tolerant and a nontolerant ecotype of Silene vulgaris. Physiologia Plantarum 101, 477-482.

Schat, H., Vooijs, R. and Kuiper, E. (1996) Identical major gene loci for heavy metal 
tolerances that have independently evolved in different local populations and subspecies of Silene vulgaris. Evolution 50, 1888-1895.

Schubert, R. (1953) The heavy metal plant communities in the eastern Harz foreland (in German). Wisssenschaftliche Zeitschrift der Martin-Luther-Unversität Halle-Wittenberg, Mathematisch-Naturwissenschaftliche Reihe 3, 51-70.

Schubert, R. (1954) The heavy metal vegetation of the Bottendorf hills (in German). Wisssenschaftliche Zeitschrift der Martin-LutherUnversität Halle-Wittenberg, MathematischNaturwissenschaftliche Reihe 4, 99-120.

Schulz, A. (1912) On the phanerogams growing on heavy metal enriched soils in Germany (in German). Jahresberichte des Westfälischen Provincialvereins für Wissenschaft und Kunst 40, 209-227.

Schwickerath, M. (1931) Violetum calaminariae of the zinc soils in the vicinity of Aachen. A plant phytosociological study (in German). Beiträge zur Denkmalspflege 14, 463-503.

Sebald, O. (1988) The genus Becium Lindley (Lamiaceae) in Africa and on the Arabian Peninsula (Part 1). Stuttgarter Beiträge zur Naturkunde, Serie A (Biologie) 419, 1-74.

SERNAGEOMIN (1989) Survey of tailings storage facilities in Chile, Stage A, Regions V and XIII (in Spanish). Servicio Nacional de Geología y Minería, Santiago, Chile.

SERNAGEOMIN (1990) Survey of tailings storage facilities in Chile, Stage B, Regions IV, V, and VII (in Spanish). Servicio Nacional de Geología y Minería, Santiago, Chile.

Shewry, P.R., Woolhouse, H.W. and Thompson, K. (1979) Relationships of vegetation to copper and cobalt in the copper clearings of Haut-Shaba, Zaire. Botanical Journal of the Linnean Society 79, 1-35.

Simon, E. (1978) Heavy metals in soils, vegetation development and heavy metal tolerance in plant populations from metalliferous areas. New Phytologist 81, 175-188.

Smith, R.F. (1979) The occurrence and need for conservation of metallophytes on mine wastes in Europe. Minerals and the

Environment 1, 131-147.

Sotiaux, A., de Zuttere, Ph., Schumacker, R., Pierrot, R. B. and Ulrich, C. (1987) Scopelophila cataractae (Mitt.) Broth. (Pottiaceae, Musci), new for continental Europe in France, Belgium, The Netherlands, and Germany (in French). Cryptogamie, Bryologie et Lichénologie 8, 95-108.

Thalius, J. (1588) Flora of the Harz Mountains, or an Enumeration of Indigenous Plant Species in the Mountains and Their Surroundings (in Latin). Frankfurt a.M.

Tonin, C., Vandenkoornhuyse, P., Joner, J., Straczek, E. J. and Leyval, C. (2001) Assessment of arbuscular mycorrhizal fungi diversity in the rhizosphere of Viola calaminaria and the effect of these fungi on heavy metal uptake by clover. Mycorrhiza 10, 161-168.

Tuomainen, M.H., Nunan, N., Lesranta, S.J. et al. (2006) Multivariate analysis of protein profiles of metal hyperaccumulator Thlaspi caerulescens accessions. Proteomics 6, 3695-3706.

Turnau, K. and Mesjasz-Przybylowicz, J. (2003) Arbuscular mycorrhiza of Berkheya codii and other Ni hyperaccumulating members of the Asteraceae from ultramafic soils in South Africa. Mycorrhiza 13, 185-190.

Van der Ent, A. (2007) Possibilities for restoration of the zinc flora in the upper Geul valley (in Dutch). De Levende Natuur 108, 14-19.

Van der Ent, A. (2008) Possibilities for restoration of heavy metal vegetation in the Geul valley (in Dutch). Radboud Universiteit Nijmegen. 126 pp.

Van de Riet, B.P., Bobbink, R, Willems, J.H., Lucassen, E. C.H.E. T. and Roelofs, J.G. M. (2005) Advice on Heavy Metal Vegetation (in Dutch). Directie Kennis, Ministerie van LNV, The Hague.

Van Ginneken, L., Meers, E., Guisson, R. et al. (2007) Phytoremediation of heavy metal-contaminated soils combined with bioenergy production. Journal of Environmental Engineering and Landscape Management 15, 227-236. 
Van Hoof, N. A. L. M., Hassinen, V.H., Hakvoort, H.W.J. et al. (2001) Enhanced copper tolerance in Silene vulgaris (Moench) Garcke populations from copper mines is associated with increased transcript levels of a 2b-type metallothionein gene. Plant Physiology 126, 1519-1526.

Viladevall, M., Santibáñez, R., Ponce, J. et al. (1994) Vegetation analysis of 'tholas' as an exploration method for antimony-gold mineralization in the high Andes of Bolivia (in Spanish). Actas $7^{\circ}$ Congreso Geológico Chileno, Volumen II. pp. 1264-1267.

Villagrán, C. and Hinojosa, L.F. (1997) The story of forest in South America II: phytogeography (in Spanish). Revista Chilena de Historia Natural 70, 241-267.

Vogel-Mikuš, K., Pongrac, P., Kump, P. et al. (2007) Localisation and quantification of elements within seeds of $\mathrm{Cd} / \mathrm{Zn}$ hyperaccumulator Thlaspi praecox by micro-PIXE. Environmental Pollution 147, 50-59.

Von Hodenberg, A. and Finck, A. (1975) Investigations on the toxic growth damage of cereals and beet in the Harz area (in German). Landwirtschaftliche Forschung 28, 322-332.

Weber, M., Harada, E., Vess, C., van RoepenackLahaye, E. and Clemens, S. (2006) Comparative transcriptome analysis of toxic metal responses in Arabidopsis thaliana and the $\mathrm{Cd}^{2+}$-hypertolerant facultative metallophyte Arabidopsis halleri. Plant, Cell and Environment 29, 950-963.

Weeda, E., Schaminée, J.H.J. and van Duuren, L. (2002) Atlas of the Plant Communities in the Netherlands. Grassland, Fringes, and Dry Heathlands (in Dutch). KNNV Uitgeverij, Utrecht. pp. 88-89.

Whitfield, L., Richards, A. and Rimmer, D. (2004) Effects of mycorrhizal colonisation of Thymus polytrichus from heavy-metal-contaminated sites in northern England. Mycorrhiza 14, 47-54.

Whiting, S. N., Reeves, R. D., Richards, D. et al. (2004) Research priorities for the conservation of metallophyte biodiversity and their potential for restoration and site remediation. Restoration Ecology 12, 106-116.

Wieshammer, G., Unterbrunner, R., Garcia, T. B. et al. (2007) Phytoextraction of Cd and Zn from agricultural soils by Salix sp. and intercropping of Salix caprea and Arabidopsis halleri. Plant and Soil 298, 255-264.

Wild, H. (1968) Geochemical anomalies in Rhodesia. 1. The vegetation of copper bearing soils. Kirkia 7, 1-71.

Wild, H. (1970) Geobotanical anomalies in Rhodesia. 3. The vegetation of nickel bearing soils. Kirkia 7 (Suppl), 1-72.

Wilson, J. B. (1988) The cost of heavy-metal tolerance: an example. Evolution 42, 408-413.

Wu, L., Bradshaw, A. D. and Thurman, D. A. (1975) The rapid evolution of heavy metal tolerance in plants. III. The rapid evolution of copper tolerance in Agrostis stolonifera. Heredity 34, 165-167.

WWF International and IUCN (1999) Metals from the forests. Mining and forest degradation. Special issue of the newsletter Arborvitae. January 1999, pp. 1-40.

Xing, J. P., Jiang, R. F., Ueno, D. et al. (2008) Variation in root-to-shoot translocation of cadmium and zinc among different accessions of the hyperaccumulators Thlaspi caerulescens and Thlaspi praecox. New Phytologist 178, 315-325.

Xiong, Z.T., Wang, T., Liu, K. et al. (2008) Differential invertase activity and root growth between Cu-tolerant and non-tolerant populations in Kummerowia stipulacea under $\mathrm{Cu}$ stress and nutrient deficiency. Environmental and Experimental Botany 62, 17-27.

Zhao, F.J., Hamon, R.E., Lombi, E., McLaughlin, M.J. and McGrath, S.P. (2002) Characteristics of cadmium uptake in two contrasting ecotypes of the hyperaccumulator Thlaspi caerulescens. Journal of Experimental Botany 53, 535-543. 